\title{
Diversity of introduced terrestrial flatworms in the Iberian Peninsula. A cautionary tale.
}

Many tropical terrestrial planarians (Platyhelminthes, Geoplanidae) have been introduced around the globe. One of these species is known to cause significant decline in earthworm populations, resulting in a reduction of ecological functions that earthworms provide.

Flatworms, additionally, are a potential risk to other species that have the same dietary needs. Hence, the planarian invasion might cause significant economic losses in agriculture and damage to the ecosystem. In the Iberian Peninsula only Bipalium kewense Moseley, 1878 had been cited till 2007. From that year on, four more species have been cited, and several reports of the presence of these animals in particular gardens have been received. In the present study we have: (1) analyzed the animals sent by non-specialists and also the presence of terrestrial planarians in plant nurseries and garden centers; (2) identified their species through morphological and phylogenetic molecular analyses, including representatives of their areas of origin; (3) revised their dietary sources and (4) used Species Distribution Modeling (SDM) for one species to evaluate the risk of its introduction to natural areas. The results have shown the presence of at least ten species of alien terrestrial planarians, from all its phylogenetic range. International plant trade is the source of these animals, and many garden centers are acting as reservoirs. Also, landscape restoration to reintroduce autochthonous plants has facilitated their introduction close to natural forests and agricultural fields. In conclusion, there is a need to take measures on plant trade and to have special care in the treatment of restored habitats. 
1 Authors:

2 Marta Álvarez-Presas $^{\mathrm{a}}$, Eduardo Mateos $^{\mathrm{b}^{*}}$, Àngels Tudó $^{\mathrm{a}}$, Hugh Jones $^{\mathrm{c}}$ \& Marta Riutort ${ }^{\mathrm{a}}$

3 Addresses:

4 a Departament de Genètica, Facultat de Biologia i Institut de Recerca de la Biodiversitat (IRBio),

5 Universitat de Barcelona, Avinguda Diagonal 643, E-08028 Barcelona, Spain

$6{ }^{\mathrm{b}}$ Departament de Biologia Animal, Facultat de Biologia, Universitat de Barcelona, Avinguda

7 Diagonal 643, E-08028 Barcelona, Spain

$8 \quad{ }^{\mathrm{c}}$ Department of Zoology, The Natural History Museum, Cromwell Road, London, SW7 5B, UK.

9 E-mail addresses:

10 onaalvarez@ub.edu (Marta Álvarez-Presas)

11 emateos@ub.edu (Eduardo Mateos)

12 angi_tuca@hotmail.com (Angels Tudó)

13 flatworm@btopenworld.com (Hugh Jones)

14 mriutort@ub.edu (Marta Riutort).

$15{ }^{*}$ Corresponding autor:

16 Eduardo Mateos

17 Email - emateos@ub.edu

18 Departament de Biologia Animal, Facultat de Biologia, Universitat de Barcelona, Avinguda 19 Diagonal 643, E-08028 Barcelona, Spain. 
Introduction

Most animal invasive species detected in Europe are terrestrial invertebrates (Roques et al., 2009). Invading edaphic organisms can have dramatic effects on the environment, due to the direct effects on native soil organisms, and through their interactions with the environment aboveground. However, overall, their impact in human health and economy is greater than their ecological impact (Vilà et al., 2010). Among these organisms, land planarians are becoming an important and diversified group of introduced species in Europe.

Terrestrial planarians (Platyhelminthes, Geoplanidae) are divided into four subfamilies (Bipaliinae, Microplaninae, Geoplaninae and Rhynchodeminae) with a cosmopolitan distribution (Winsor, Johns \& Yeates, 1998); however, most species are found in the southern hemisphere. Bipaliinae (Fig. 1A) is absent from the American and European continents, Geoplaninae (Fig. 1B) have an exclusively Central and South American distribution, while Microplaninae (Fig. 2A) and Rhynchodeminae (Fig. 2B) are the subfamilies with the most northerly distribution, including Europe. Terrestrial planarians are the only free-living Platyhelminthes that do not live in an aquatic habitat. However, they have not developed the capacity to prevent water loss and are thus strongly dependent on environmental moisture level (Froehlich, 1956; McDonald \& Jones, 2007). They seem to withstand this limitation through behavioral strategies, such as hiding in damp refuges during the day and becoming active during the night. Due to these characteristics, these animals are considered to have a low capacity to disperse. In fact, in their areas of origin, although a few species are well-adapted to open and human-transformed lands (Baptista \& LealZanchet, 2010), most species are restricted to humid forest areas.

A total of 36 species of terrestrial planarians are known to have been introduced in different countries around the globe. Most of these species have a big effect on terrestrial ecosystem processes because they prey on soil invertebrates (see references in Winsor, Johns \& Barker, 2004). So far, five of these species are considered to be either invasive and cause problems with local biodiversity (Platydemus manokwari De Beauchamp, 1963), or horticultural pests (Arthurdendyus triangulatus (Dendy, 1894)) or earthworm farm pests (Bipalium adventitium Hyman, 1943; Bipalium kewense Moseley, 1878; Dolichoplana striata Moseley, 1877, see Winsor, Johns \& Barker, 2004).

In Europe there is evidence of the presence of at least 18 introduced terrestrial planarians (Minelli, 1977; Ball \& Reynoldson, 1981; Jones, 1988; 1998; Mateos, Giribet \& Carranza, 1998; Faubel, 2004; Jones et al., 2008 Vila-Farré et al., 2008; 2011; Justine et al., 2014). In the Iberian Peninsula (IP) there are only a few published records of introduced terrestrial planarians, and the 
only species cited are Bipalium kewense in Barcelona (Filella-Subirá, 1983), Platydemus sp. in Málaga (Vila-Farré et al., 2011), Obama sp. in Asturias (Fernández et al., 2013) and Rhynchodemus R02 and Caenoplana coerulea Moseley, 1877 in Girona (Mateos et al., 2013). The last species has also been cited in Menorca (Breugelmans et al., 2012).

After receiving multiple reports from non-scientists on the presence of "large and colored" terrestrial flatworms in several localities in the IP, and given their observed locations, particularly in private gardens, we decided to analyze their presence in garden centers and plant nurseries.

The aims of this work were to: (1) Estimate the number of terrestrial flatworm species introduced in the IP, and find their region of origin; (2) check whether plant nurseries and garden centers are acting as entrance gates and reservoirs; (3) estimate the invasive potential of some introduced species by considering their diet and by using Species Distribution Modeling (SDM); (4) propose measures to prevent their becoming invasive and to prevent further introductions and spread.

Material and methods

Specimen collection

Specimens were sampled from four sources (Tables 1 and 2): (1) gardens, (2) nurseries and plantations, (3) semi natural areas, and (4) from other countries (either the original area of distribution or other invaded areas). Specimens from sources 1 and 2 were either sent by people who knew our work through the information in social networks, or sampled by us (all the localities reported by non-scientist collaborators correspond to gardens). Specimens from source 3 were sampled by us. Specimens from source 4 were sent by colleagues, specialists of the group, to whom we requested material for comparison with the Iberian populations.

Data from a total of 13 domestic gardens, seven nurseries, two plantations (all confined, humanized locations), and three semi-natural areas (humanized environments that are not confined and in direct contact with agricultural and forest areas) have been analyzed (Table 1). The three "semi natural areas", located in North-eastern Iberian Peninsula, were: (1) Cal Tet, Parc Natural Delta del Llobregat, Barcelona (Fig. 3, Loc-code O); (2) Can Cabanyes, Granollers, Barcelona (Fig. 3, Loc-code M); (3) Viaducte de Rubiò, Vall d'en Bas, Girona (Fig. 3, Loc-code P). In all three places recent habitat restoration activities have been performed, including the transplantation of autochthonous plant species from commercial nurseries. 
Amateur collaborators photographed the animals alive and fixed them in absolute ethanol. Specimens collected by us were also photographed and external morphological characters recorded. Subsequently, animals were subjected to two different procedures to proceed to the species identification: (1) specimens for molecular analyses were fixed in 100\% ethanol and (2) specimens for histological studies were killed with boiling water, fixed with $10 \%$ formalin for 24 hours, and then preserved in $70 \%$ ethanol.

\section{Morphological studies}

Preserved specimens were examined under a stereo microscope and notes of their dimensions, appearance, color (though this is affected by preservation), eyes, any stripes or pattern, the position of the pharyngeal aperture (mouth) and gonopore, if present, were taken. Specimens with no visible gonopore were considered to be immature. It was possible to identify some specimens, even immature ones, to species level without further examination. For unrecognized specimens, or where identity was uncertain and required confirmation, a mature specimen (evidenced by an open gonopore) was selected and divided into various portions, being embedded in wax. The copulatory apparatus (gonopore) and a small anterior region were sagittally and transversely sectioned at 10 or $15 \mu \mathrm{m}$, respectively, stained in Harris' haematoxylin and eosin and mounted in Canada balsam.

\section{DNA extraction, gene amplification and sequencing}

A small piece of tissue fixed in absolute alcohol was digested with Wizard Genomic DNA Purification lysis Buffer (Promega, Madison, WI, USA) and Proteinase $\mathrm{K}$ overnight at $37^{\circ} \mathrm{C}$, following manufacturer's instructions. The rest of the tissue is kept as voucher in the Genetics Department (Universitat de Barcelona).

We amplified an approximately $1 \mathrm{~kb}$ fragment of the mitochondrial cytochrome c oxidase I (Cox1 gene) and a fragment of approximately 1,500 bp of the 28S rRNA gene (28S) by PCR reaction. PCRs were carried out in a volume reaction mixture of $25 \mu 1$. For Cox1 we used primers BarS (Álvarez-Presas et al., 2011) and COIR (Lázaro et al., 2009) and conditions were as in Álvarez-Presas et al. (2011); 28S rDNA gene was amplified in two different overlapping fragments using the primers $28 \mathrm{~S} 1 \mathrm{~F}, 28 \mathrm{~S} 4 \mathrm{R}, 28 \mathrm{~S} 2 \mathrm{~F}$ and $28 \mathrm{~S} 6 \mathrm{R}$, and conditions as in ÁlvarezPresas et al. (2008). Amplification products were purified with a vacuum manifold (Multiscreen_HTS Vacuum Manifold, Millipore Corporation, Billerica, MA 01821, USA). DNA sequences were determined from both strands using Big-Dye Terminator (3.1, Applied 
115 Biosystems, Foster City, CA, USA) and the reaction products were separated on the ABI Prism

1163730 automated sequencer (Unitat de Genòmica dels Centres Científics i Tecnològics de la UB).

117 PCR products of the $28 \mathrm{~S}$ gene for some individuals, that yielded double bands in the 118 direct sequences, were cloned using HTP TOPO TA Cloning Kit for Sequencing (Invitrogen) in 119 order to be sure that only one type of sequence was recovered (since the existence of a 120 duplication of the ribosomal cluster is known in terrestrial planarians, Carranza et al., 1996). The 121 sequences of the clones showed that these bands corresponded to polymorphisms of one of the 122 types. Seqman (v. 4.2.2, Gene Codes) was used to revise the chromatograms and obtain the 123 definitive sequences.

124

\section{Molecular data analyses}

Ribosomal sequences were aligned using MAFFT v. 7 (Katoh \& Standley, 2013) with the G-INS-i iterative refinement method and 1000 cycles. Mitochondrial coding DNA sequences were translated into aminoacids and aligned manually in Bioedit v.7.0.9.0. (Hall, 1999). All sequences were unambiguously aligned. We estimated the DNA sequence evolution model that best fits the data for both molecules using jModelTest 2.1.4. (Darriba et al., 2012), applying the Akaike information criterion (AIC). Phylogenetic relationships were estimated by Maximum Likelihood (ML) using RAxML 7.0.0 software (Stamatakis, 2006) and Bayesian inference (BI) using MrBayes v. 3.2. (Ronquist et al., 2012). Bootstrap support (BS) values were obtained for ML trees from 10,000 replicates. In the BI analyses we ran four chains to allow heating and used default priors, three million generations were run using the Markov Chain Monte Carlo (MCMC) analysis in two independent runs. Sampling was every 1000 generations. The stationarity and convergence of the runs were checked by plotting Log likelihood values vs number of generations and inspecting when the standard deviation of split frequencies had reached $<0.01$, respectively.

\section{Potential distribution modeling}

Using data describing the known distribution of C. coerulea in Australia, we estimated the potential distribution of this species in the Iberian Peninsula, as an exercise to find out whether climatic variables could detect potentially at risk areas where the establishment of the introduced species will be favored if only affected by climate. This could be a tool to help limit potential 
activities in order to avoid the introduced animals becoming invasive in the most likely areas for them to be successful.

For the SDM, a total of 179 Australian geographical coordinates of presence observations extracted from the literature, internet sources and personal communications (L. Winsor, 2013) were used for calibration of models (training dataset). To avoid over-parameterization and loss of predictive power, we discarded the climatic variables that were highly correlated. To do this we extracted environmental information from 10,000 randomly generated points and determined the linear relationships among them using Spearman and Pearson correlations. Although all correlations were significant they show low correlation coefficients $(r<=0.12)$. According to this analysis we used the 9 bioclimatic variables from the WorldClim database v. 1.4. (http://www.worldclim.org/, Hijmans et al., 2005) with less dependence, to form the present climatic dataset at a scale of 30 arc seconds. Those variables were: annual mean temperature; mean diurnal range; isothermality; maximum temperature of warmest month; minimum temperature of coldest month; precipitation of wettest month; precipitation seasonality; precipitation of wettest quarter; and precipitation of warmest quarter. The maximum entropy model, a presence-only algorithm that requires known species occurrence points and environmental variables (Maxent v.3.3.3k; Phillips, Anderson \& Schapire, 2006), was applied. We selected the software default values for the convergence threshold, regularization values, and features. The maximum number of iterations was set to 1,000 and 1,000 bootstrap replicates were used. All possible geographic locations were partitioned between training and test samples (75\% and 25\%, respectively) in order to achieve higher predictive accuracy (Phillips \& Dudík, 2008). Once the models were trained, we projected the results using the IP climatic dataset, to study the possible expansion of $C$. coerulea in the region. Model performance was evaluated using the AUC test (area under the receiver operating characteristic curve (ROC)) and the binomial test of the omission-dependent threshold was calculated by Maxent. Finally, binary maps of the outcome of the models were overlapped in the geographic information system, ArcMap v.10 (ESRI 2011. ArcGIS Desktop: Release 10. Redlands, CA: Environmental Systems Research Institute).

Results Morphological identification of the specimens

Based on the external appearance of the flatworms we initially grouped the specimens into nine morphotypes. We classified four of them at the species level due to their characteristic shapes or other external features, and the other five at genus or tribe level. 
Bipalium kewense (Fig. 4) has been identified by the characteristic shape of the anterior

177

178

179

180

181

182

183

184

185

186

187

188

189

190

191

192

193

194

195

196

197

198

199

200

201

202

203

204

205

206

207

end and the pattern of stripes along the dorsal and ventral body surfaces. One specimen preserved in $70 \%$ ethanol from Bordils locality (Loc code V in Table 1) has been deposited at the Natural History Museum of the United Kingdom (NHMUK) with voucher number NHMUK 2014.5.13.6.

For Caenoplana bicolor (Graff, 1899) there is no published description of a sexually mature specimen, hence the identification of the only specimen obtained, also an immature individual, relied exclusively on its external appearance (Fig. 5). This specimen is deposited in the tissue collection of the Genetics Department (Universitat de Barcelona).

Among the specimens with an external morphology initially ascribable to the Caenoplana coerulea phenotype, we have found two morphotypes basing on their color pattern. Morphotype Ca1 (Fig. 6) presents a dorsal coloration in dark blue with a yellow middle-dorsal stripe, and a ventral light blue region (characteristic pattern of Caenoplana coerulea). The histological study of one specimen from El Prat de Llobregat locality (Loc code O in Table 1) (NHMUK 2014.5.13.14) reveals that it may belong to Caenoplana coerulea species. Morphotype Ca2 (Fig. 7) presents a light brown dorsal region with a pale yellow middle-dorsal stripe, and a ventral light blue-greenish region. The histological study of one specimen from Bordils locality (Loc code V in Table 1) (NHMUK 2014.5.13.12) has revealed that its copulatory apparatus characters do not fit any of the described Caenoplana species.

Dolichoplana striata (Fig. 8) could also be identified by its characteristic external appearance. One specimen from Bordils locality (Loc code V in Table 1) has been deposited at the NHMUK (NHMUK 2014.5.13.7).

Kontikia ventrolineata (Dendy, 1892) (Fig. 9) was externally identified, following NNSS (2013). We assigned the specific name following Jones, Johns \& Winsor (1998), who considered Parakontikia Winsor, 1991 as junior synonym of Kontikia Froehlich, 1955. Three specimens from Granollers locality (Loc code $M$ in Table 1) are deposited at the NHMUK (NHMUK 2014.5.13.3-5).

We found one morphotype externally ascribable to the genus Rhynchodemus, but not to a known species (Fig. 10). Rhynchodemus morph Rs1 has a dark brown pigmented body with two black longitudinal stripes, and two large eyes situated a little distant from the anterior tip. One specimen from Vall d'en Bas locality (Loc code P in Table 1) (NHMUK 2014.5.13.9) was histologically studied but, unluckily, presented a copulatory apparatus not well developed, 
208

209

210

211

212

213

214

215

216

217

218

219

220

221

222

223

224

225

226

227

228

229

230

231

232

233

234

235

236

237

238

239

preventing us from determining whether it could belong to Rhynchodemus sylvaticus (Leidy, 1851) to which it was extremely externally similar.

A morphotype externally ascribable to the tribe Rhynchodemini was found in Benamargosa locality (Loc-code G), but its morphological features did not allow assigning it to any genus. Rhynchodemini morph Ri1 presents a dark brown pigmented body with one dorsal black line (no image available).

Specimens of Obama sp. (Fig. 11) have a characteristic leaf-shaped, broad, flattened body. Externally, they are very similar to Obama sp. 6 sensu Carbayo et al., 2013 from Brazil (Fernando Carbayo personal communication). One specimen from Bordils locality (Loc code V in Table 1) is deposited at the NHMUK (NHMUK 2014.5.13.8).

\section{Phylogenetic results}

We inferred ML trees to check the diagnosis of the introduced specimens and to determine their level of relatedness to the ones from the original areas of distribution. For this reason, the datasets included, when possible, sequences belonging to morphologically diagnosed specimens from the original area of distribution of the putative introduced species (obtained for this study or coming from GenBank; Table 2).

We obtained 28S sequences for 15 individuals. One or two sequences from each morphotype were aligned together with 19 GenBank ingroup sequences and 3 outgroup sequences belonging to the Dugesia genus (terrestrial planarians sister group; Carranza et al., 1998; Álvarez-Presas, Baguñá \& Riutort, 2008). Cox1 sequences were obtained for all individuals included in the study (Table 2). To obtain a more detailed picture of the situation within the main clades, including introduced planarians found on the concatenated analysis, we split the Cox1 sequences into four new datasets, one for each subfamily, tribe or genus: Caenoplanini (56 ingroup +4 outgroup), Geoplaninae (26 ingroup sequences +2 outgroup), Bipaliinae (9 ingroup +3 outgroup) and Rhynchodemini (29 ingroup +4 outgroup). For each clade, its sister group was selected as the outgroup as shown on the concatenated analysis and/or previous studies (Álvarez-Presas et al., 2008). The best-fit model of sequence evolution for the $28 \mathrm{~S}$ was $\mathrm{GTR}+\mathrm{G}$ and for Cox1 was $\mathrm{GTR}+\mathrm{I}+\mathrm{G}$. We inferred a ML tree with partitions from a concatenated dataset including 37 individuals for which both $28 \mathrm{~S}$ and Cox 1 sequences had been obtained (Fig.12). The ML trees obtained from the Cox1 datasets are shown in Figs. 13-16.

For the concatenated dataset, the ML tree showed most introduced specimens constitute monophyletic groups together with representatives of their species coming from the original 
240

241

242

243

244

245

246

247

248

249

250

251

252

253

254

255

256

257

258

259

260

261

262

263

264

265

266

267

268

269

270

271

distribution area or other introduced localities. We have found introduced planarians in the IP for all non-autochthonous terrestrial planarians subfamilies; in the case of the Rhynchodeminae there are even representatives from two tribes (Rhynchodemini and Caenoplanini).

Within the Bipaliinae, Bipalium specimens found in the IP constitute a monophyletic group together with Bipalium sequences from other species, B. adventitium being the closest relative in the Cox1 tree (Figs. 12 and 13). The genetic diversity among the four $B$. kewense sequences, coming from the IP and Açores Islands, was very small.

In the Geoplaninae clade (Figs. 12 and 14) the introduced specimens found in the IP constitute a monophyletic group with a still not-described species from Brazil (Obama sp. 6 after Carbayo et al., 2013, Fig. 14). In the Cox1 tree, specimens coming from the IP, United Kingdom (both introduced) and Brazil (original area) constitute a highly-supported monophyletic group. Within this group, the introduced individuals are divided in two quite differentiated clades (Obama sp.A and Obama sp.B in Fig 14), also distinctly separated from the Brazilian individuals. All the UK individuals fall within the clade Obama sp.A.

The Caenoplanini clade (Figs. 12 and 15) includes a high number of introduced individuals and the broadest diversity of sequences. Even Caenoplana coerulea sequences, either coming from GenBank, or from the individuals sent by our collaborator in Australia, are found in very distinct genetic clades pointing to the existence of more than one species (see Discussion). For this reason, we use the name Caenoplana coerulea s.l. to refer to all those specimens. In the concatenated tree, the representative of Caenoplana morphotype $\mathrm{Ca} 1$ is closely related to Caenoplana coerulea s.1. from Australia, while Caenoplana morphotype $\mathrm{Ca} 2$ is the sister group of a clade constituted by $C$. coerulea s.l. and C. bicolor. The divergence among these three lineages can be appreciated when compared to the other subfamilies present in the tree. In the Cox1 tree (Fig. 15) genus, Caenoplana again shows high levels of genetic diversity, evidenced by the long branches separating its subclades. Most Caenoplana morphotype Ca1 from the IP constitute a low diversity clade including C. coerulea s.l. from its original area (Australia) and also from UK and Menorca (also introduced). This clade is sister to another group including $C$. coerulea s.1. originally from different localities in Australia (Sunnucks et al., 2006); however, the differentiation among these two clades is extremely high. The other two Caenoplana morphotype Ca1 individuals, coming from Townsville (Australia), constitute a highly differentiated clade that also includes a GenBank sequence identified only to the genus level and one of the introduced individuals. Finally, there is a clade including only introduced animals, one of them identified as 
272

273

274

275

276

277

278

279

280

281

282

283

284

285

286

C. bicolor and the rest as morphotype $\mathrm{Ca} 2$. The genetic differentiation between the two lineages within this clade is nonetheless extremely high.

In the Rhyncodemini clade (Figs. 12 and 16) we find representatives of three genera in the IP. Dolichoplana striata sequences form a monophyletic clade in the Cox1 tree, including three introduced animals in the IP and one coming from Brazil. The individuals assigned to Rhynchodemini morphotype Ri1 collected in Málaga (Spain, Loc code G in Table 1; Vila-Farré et al., 2011) cannot be assigned to any species, although they probably belong to Dolichoplana given the relationships they show in the Cox 1 tree. The four $K$. ventrolineata specimens analyzed constitute a monophyletic group with a low variability, the French representative being the more divergent. The genus Rhynchodemus is represented by at least three species in the Cox 1 tree. Rhynchodemus sylvaticus (considered an European autochthonous species), Rhynchodemus morphotype Rs1, and a clade including two individuals from Panama that we had ascribed to the Rhynchodemini by their external appearance, and they appear likely to belong to the genus Rhynchodemus. It should be noted that the specific identification of all $R$. sylvaticus specimens found in the IP (Boix and Sala, 2001; Mateos et al., 2009; Vila-Farré et al., 2008; 2011) have been made based exclusively on external morphology (for this reason all these specimens have been considered Rhynchodemus cf. sylvaticus). Rhynchodemus cf. sylvaticus clade, including representatives from Spain, Portugal, UK and France, together with a specimen identified in a previous study (Rhynchodemus cf. sylvaticus (Canyamars)), is sister group of a clade constituted by Rhynchodemus morphotype Rs1 and one specimen of $R$. cf. sylvaticus (specimen 219).

\section{Specimen distribution}

Figure 3 and Tables 1 and 2 show the sampling localities of the animals analyzed in this study. In all the plant nurseries, only one species of terrestrial planarian was found (Bipalium kewense, Rhynchodemini Ril or Obama sp.), except in Bordils where six species were found (Table 1, Loc-code V). The rest of the localities also contained a single species, with the exception of Treto (a garden, Loc-code U) with two species, and the two "semi natural areas" situated in Vall de'n Bas (Loc-code P) and in Granollers (Loc-code M) also with two species each. Obama sp. was the species most frequently found in plant nurseries, while $B$. kewense predominated in private gardens. In the semi natural areas only the species $K$. ventrolineata, $C$. coerulea s.1., and Rhynchodemus Rs1 (not found anywhere else) have been found. 
Potential species distribution modelling

The result of projecting models for the potential distribution of $C$. coerulea s.l. in the IP presents mean values of AUC beyond 0.9 (0.974) and significance for all tests of omission, which indicates good performance of the models. Furthermore, predictions were significantly different from random because binomial omission test thresholds were significant $(p<0.01)$ in all 1,000 runs. A composite map showing the potential distribution models for C. coerulea s.l. species projected on current climate layers is provided in Fig. 17.

The results of the potential distribution of the species in the IP, based on data from its current distribution in their region of origin (Australia), show that the species can find extremely suitable areas for its survival and expansion is the northern region, where the appropriate temperature and humidity conditions occur.

\section{Discussion}

Species identification, or, how many species are out there?

External morphology (Figs. 4-14), analysis of histological sections, and phylogenetic inference from molecular data (Figs. 12-16) have revealed the presence of five clearly identifiable species of introduced exotic land planarians in the IP: Bipalium kewense (Bipaliinae), Caenoplana bicolor, Caenoplana coerulea s.l. (Ca1), Dolichoplana striata (Rhynchodeminae, Rhynchodemini), and Kontikia ventrolineata (Rhynchodeminae, Caenoplanini). However, the phylogenetic trees obtained and the analysis of the external appearance of the specimens indicate that probably at least five more species were present, including Rhynchodemini morph Ril, Rhynchodemus morph Rs1, Obama sp. and two more species within Caenoplana: Caenoplana morph $\mathrm{Ca} 2$ and probably some individuals of Caenoplana morph Ca1 (see below).

The assignation of Bipalium kewense is based on its characteristic external morphology (see Hill \& Merickel, 2011; Jones, 1998). There are no published Cox1 gene sequences for this species in Genbank, so those presented in this paper are the first available. Phylogenetic analysis of these sequences point to an introduction from the same lineage. Surprisingly, all sequences belonging to Kontikia ventrolineata (coming from Spain, France and UK) are situated within the Rhynchodemini clade with high support in both trees. This situation contradicts the taxonomy of Sluys et al. (2009) where the genus Kontikia belongs to tribe Caenoplanini.

The genetic differentiation observed within the group constituted by the genus Caenoplana, monophyletic in the trees, leads us to predict that it includes more than one species. 
333 In the Cox1 tree (Fig. 15), at least three monophyletic groups seem to be clearly defined and 334 probably represent different species. In fact, $C$. coerulea is considered by a specialist in this 335 group (L. Winsor, personal communication) as a complex of species, on the basis of internal 336 anatomical characters and stripe morphology. According to Winsor, there are at least three species 337 that are distinguishable morphologically; but there are probably more than three species in the 338 area of origin. One of the problems with the group is that the type of the species is non-sexually 339 mature. Hence, to clarify the situation and number of the species in this group, a broad sampling 340 in its original area of distribution is required, followed by a thorough morphological and 341 molecular study. Nonetheless, for the purpose of the present paper, the evidence is clear that at 342 least three different genetic lineages from Australia have been introduced in the IP, probably 343 independently.

$344 \quad$ In the case of Rhynchodemus Rs1, we cannot be sure if this is a distinct species or simply 345 a differentiated lineage of $R$. cf. sylvaticus. The latter has been generally regarded as an 346 introduced species in Europe from USA (Jones, 1988), but it is also considered as probable 347 species native to Europe (Jones, 1998; 2005) and introduced in the USA from Europe (Ogren \& 348 Kawakatsu, 1998). The type locality of $R$. sylvaticus is Philadelphia, Pennsylvania, USA (1851). 349 This species has a wide distribution in the IP and two of the locations are plant nurseries, one in 350 Barcelona (Vila-Farré et al., 2008) and one in Málaga (Vila-Farré et al., 2011), while the other 351 localities can be considered natural habitats. In our molecular analysis there was no separation of 352

Dolichoplana; however, we were only able to obtain three specimens and none of them were sexually mature.

When specimens of Obama sp. were first found in the UK and the IP, they were identified as O. marmorata (Schultze \& Müller, 1857) due to their external appearance; however, molecular data (unpublished) showed that the European specimens did not constitute a monophyletic group with that species, indicating that they belonged to an unknown, still undescribed, Geoplaninae.

362 Sampling performed in Brazil since then has found another species (Obama sp.6), which is also 363 externally very similar. Molecular data show that it is closely related to the individuals found in 364 Europe (unpublished). As in the previous case, a morphological and molecular study should be 365 undertaken to clearly delimit and describe the new species. The two clades found in our Cox 1 
tree (Fig. 14), that may represent two different species, suggest that there have been two independent introductions into the IP from different native sites in Brazil.

Overall, we have shown that at least ten introductions have occurred in the IP. These introductions include species from all the non-European terrestrial planarian subfamilies from native localities as far as South America and Australia. Since most of these species have previously been reported to have been introduced in other countries, the introductions into the IP have probably not been directly from the source countries, but were more likely to be indirect, following plant trade routes. In most cases, all the individuals from the same species found in the different localities are nearly identical, even when compared between Spain and the UK, which can be interpreted as the result of a single introduction (or a single exportation from the place of origin). In others, as in the case of Caenoplana, the observed diversity clearly indicates that the introductions were from different lineages within this group and is likely to be the consequence of more than one export from the native area.

\section{What makes terrestrial planarians so successful as introduced species?}

Temperature, humidity and food availability are the three basic factors determining the geographical distribution of terrestrial planarians (Boag, Yeates \& Johns, 1998). The feeding habits of the introduced species in the IP indicate that all of them feed on invertebrate soil fauna (Table 3). In plant nurseries and greenhouses microclimatic conditions are maintained artificially (high humidity and stable temperature) and are likely to favor the presence of stable populations of many species of terrestrial invertebrates. In nurseries visited by us, especially under flowerpots, we have observed the presence of numerous specimens of snails, slugs, earthworms, millipedes, isopods, beetles and various groups of microarthropods, including springtails. Therefore, in this very suitable artificial microhabitat, there is likely to be a greater number of species of terrestrial flatworms (as is the case of Bordils, Loc code V in Table 1, where six species were detected in the same greenhouse).

Land planarians and their cocoons are very often associated with the soil of plants in pots and certain types of fresh vegetables (Ogren, 1985; Mather \& Christensen, 1992; Hogan \& Dundee, 1996). The transport of these pots and materials (which can occur over international and intercontinental distances) may permit the transport of associated planarians and/or cocoons, which is the primary means of introduction of exotic species of terrestrial planarians into different contaminated countries (Winsor, Johns \& Barker, 2004). The suitable conditions in the 
plant nurseries and garden centers may explain their introduction success. In recent decades, the adoption of free market policies and trade agreements have reduced barriers to plant trade among different countries (Dehnen-Schmutz et al., 2010), but there has been insufficient attention given to how such structural change in international trade can affect the risk of spread of invasive species (Drew et al., 2010). Depending on the intricate network of commercial interactions among European countries (see Dehnen-Schmutz et al., 2010), we expect a huge European dispersal of exotic animal species associated with this trade.

\section{Will planarians become invasive in the Iberian Peninsula as has occurred in other areas?}

Exotic species present in an area could be categorized as introduced (detected in the area but with unknown status), adventives or not established (they reproduce occasionally in the area not constituting stable populations), naturalized or established (they form stable reproductive populations in the area) and invasive (established and well spread in the area) (Richardson et al., 2000; Simberlof et al., 2013). The "tens rule" (Williamson \& Fitter, 1996; Williamson \& Brown, 1986; Williamson, 1996) predicts that just one of hundreds of introduced species becomes invasive (about $10 \%$ of the introduced species are established, and that $10 \%$ of those become invasive). Based on the premise of the "tens rule", some researchers minimize the potential impact of exotic species (National Research Council, 2002; Campbell \& Gibson, 2001), while others warn that this risk minimization is dangerous and, with respect to the possible impact of introduced species, the adoption of the precautionary principle is crucial (Jaric \& Cvijanovic, 2012), but unlikely! The problem with this sort of assumption or calculation is that, in most cases, we simply have no knowledge of the unsuccessful introductions.

In the case of terrestrial planarians, some species are very tolerant of habitat modification (Cannon et al., 1999; Carbayo, Leal-Zanchet \& Vieira, 2002), facilitating their survival in humanized environments. Many introduced species of terrestrial planarians are found confined to these types of habitats (parks, private gardens, plant nurseries), but it is not known whether this distribution is so restricted due to environmental constraints (planarians, coming from tropical habitats cannot live outside these artificial habitats in the European environment) or to a low velocity of dispersion to natural habitats (Ducey \& Noce, 1998). In our case, most specimens occurred in confined areas (gardens and nurseries). However, Rhynchodemus Rs1, C. coerulea s.l. and $K$. ventrolineata have been also found in recently restored areas that were more or less 
connected to natural and agricultural environments, which increases the danger of their becoming naturalized or even invasive.

In the particular case of C. coerulea s.1., we performed a potential distribution study to check whether the area around its present introduced localities in the IP may be suitable for its expansion. The results show that the potential distribution of the species (Fig. 17) indeed includes the countryside that was nearby to the localities of the IP where it is already present. The most suitable area is the northern IP. This is not surprising when we consider that in this northern region, the climatic conditions (temperature and humidity) are also more optimal for the presence of native land planarians (Mateos et al., 2009; Álvarez-Presas et al., 2012). Thus, we show that by having suitable climatic databases, it is possible to model the potential distribution of introduced species, and thus predict their risk of becoming invasive. If we add to this information the knowledge of some biological features of the terrestrial planarian species, such as their prey preferences, we may be able to make an even more precise image of the sites where it is more likely for the species to become invasive and thus concentrate prevention efforts in those areas.

Our results show that $C$. coerulea s.l. is apparently the most successful colonizer, since it is the only species present in all three unconfined (semi-natural) areas sampled. This may be because it feeds on several groups of arthropods that are abundant in areas where this species has been detected (isopods, beetles, diplopods). The three species (Rhynchodemus Rs1, C. coerulea s.l. and K. ventrolineata) we find in unconfined environments feed on arthropods, whereas the other species (found only in confined environments) do not feed on arthropods, but instead on other invertebrates that require extremely wet habitats. Hence, land planarian species that feed on arthropods have their food "secured" in environments with a Mediterranean climate and, as a consequence, have a higher likelihood of being successful and becoming established or even invasive.

What consequences might the introduction of flatworms have on human economies and biodiversity?

Another important question is: what are the negative effects of the spread of these species? In literature, the primary problems reported are related to economic consequences for agricultural activities (Boag \& Neilson, 2006; Boag, Neilson \& Jones, 2010). As predators of earthworms, planarians can cause soil drainage and fertility to be severely compromised. The ecological consequences of the presence of these predators depends on their propagation speed 
and efficiency, but could have significant effects on processes mediated by earthworms in both agroecosystems and forests (Lilleskov et al., 2010). Although there is still no direct impact study of the presence of invasive planarians on agricultural production (Boag, Neilson \& Jones, 2010), data from farmers with infested farmland and from the scientific literature have suggested that it could reduce grass yields significantly (Boag \& Neilson, 2006).

No reference has been made to the effect of these species on autochthonous populations of terrestrial planarians, probably because the knowledge of the autochthonous fauna is very scarce. In the IP we have already performed some studies on the autochthonous terrestrial planarian fauna and found that it is very diverse, including at least 15 species, of which some contain a great deal of genetic diversity (Mateos et al., 2009; Álvarez-Presas et al., 2012). The potential arrival of some of these introduced species in natural habitats, where the autochthonous ones are localized (as predicted by the potential distribution studies), would have very negative consequences. Since exotic planarians are, in general, bigger in size, more voracious, have more aggressive behavior, and sometimes appear to have a generalist diet (pers. obs.), they may be more resistant to extreme conditions than the native species.

\section{$\underline{\text { A cautionary tale: Plant trading and landscape restoration }}$}

An important question raised by all these observations is whether governments in Europe should be asked to propose new, more restrictive rules on the trade of plants coming from outside, or alternatively, to establish better controls or protocols to avoid the introduction of unwanted organisms together with the plants. However, it is probably now too late to have an impact on the transport of species around the world. Nonetheless, we are still in time to avoid invasions of terrestrial planarians. The restoration of degraded areas involves planting native plant species. These plants are available from nurseries and transported to the restoration areas accompanied by a certain amount of soil on the roots. If this land is not subject to any preventive treatment, it may be contaminated with organisms that are also introduced in the area that is being restored. Among these organisms may be unwanted species that, if given the right conditions, can become invasive. It is important to warn agencies conducting such restorations of these dangers and ask stakeholders to include in the protocols of landscape restoration the necessary steps to avoid these unwanted introductions.

Some simple, easy-to-perform sanitizing procedures, such as heating the soil (EPPO, 2000a; 2000b; SEERAD, 2000; Sugiura, 2008) before transplanting the nursery plants to the 
489

490

491

492

493

494

495

496

497

498

499

500

501

502

503

504

505

506

507

508

509

510

511

512

513

514

515

516

517

518

519

520

521

522

523

524

natural environment, may be sufficiently effective and reliable to ensure that there is no concomitant dispersal of flatworms. Such procedures, together with a periodic analysis of the introduced species present in garden centers and nurseries, and a study of the potential areas of flatworm distribution, would also help avoid the introduction of terrestrial planarians into areas where they are more likely to become invasive (DEFRA, 2005; DOVE, 2012).

Acknowledgements

Alberto Gayoso, Álvaro Leal, Cristina Cabrera, César de Inés, Carmen Soler, Dani Boix, Eduard Solà, Georgina Gratacós, Jacobo Martín, Laia Leria, Miquel Vila, Roberto Sáez, Salvador Carranza, S. Graham, Vicent Sancho and Xavier Béjar for sending specimens, pictures or information about introduced terrestrial flatworms in Spain. Isadora Christel Jiménez for support in generating GIS maps. Fernando Carbayo and Leigh Winsor for giving specimens of invasive species from their locality of origin. Alejandro Sánchez-Gracia for his help in correlation analyses for potential distribution prediction. The "Parc Natural del Delta del Llobregat" staff. Dr. Hannah Buckley, Dr. Leigh Winsor, Dr. Jean-Lou Justine and other anonymous reviewer provided helpful comments that improved the manuscript.

\section{References}

Álvarez-Presas M, Baguñà J, Riutort M. 2008. Molecular phylogeny of land and freshwater planarians (Tricladida, Platyhelminthes): from freshwater to land and back. Molecular Phylogenetics and Evolution 47(2):555-568.

Álvarez-Presas M, Carbayo F, Rozas J, Riutort M. 2011. Land planarians (Platyhelminthes) as a model organism for fine-scale phylogeographic studies: understanding patterns of biodiversity in the Brazilian Atlantic Forest hotspot. Journal of Evolutionary Biology 24:887-896.

Álvarez-Presas M, Mateos E, Vila-Farré M, Sluys R, Riutort M. 2012. Evidence for the persistence of the land planarian species Microplana terrestris (Müller, 1774) (Platyhelminthes, Tricladida) in microrefugia during the Last Glacial Maximum in the northern section of the Iberian Peninsula. Molecular Phylogenetics and Evolution 64:491499.

Baguñà J, Carranza S, Paps J, Ruiz-Trillo I, Riutort M. 2001. Molecular taxonomy and phylogeny of Tricladida. In: Littlewood DTJ, Bray RD, eds. Interrelationships of the Platyhelminthes. London: Taylor and Francis, 49-56.

Ball IR, Reynoldson TB. 1981. British Planarians. Cambridge: Cambridge University Press.

Baptista VA, Leal-Zanchet AM. 2010. Land flatworm community structure in a subtropical deciduous forest in Southern Brazil. Belgian Journal of Zoology 140(suppl):83-90.

Barnwell GM. 1978. Geoplana vaga, as sexually reproducing terrestrial planarian in San Antonio. The Southwest Naturalist 23:151-152. 
Boag B, Yeates GW, Johns PM. 1998. Limitations to the distribution and spread of terrestrial flatworms with special reference to the New Zealand flatworm (Artrioposthia triangulata). Pedobiologia 42:495-503.

Boag B, Neilson R. 2006. Impact of New Zealand flatworm on agricultura and wildlife in Scotland. Proceedings of Crop Protection in Northern Britain Conference 2006:51-56.

Boag B, Neilson R, Jones HD. 2010. Quantifying the risk to biodiversity by alien terrestrial planarians. Aspects of Applied Biology 104:55-61.

Boix, D. \& Sala, J. 2001. Presència del gènere Rhynchodemus (Platyhelminthes, Tricladida, Terricola) a la Península Ibérica. Scientia Gerundensis 25:31-32.

Breugelmans K, Cardona JQ, Artois T, Jordaens K, Backeljau T. 2012. First report of the exotic blue land planarian, Caenoplana coerulea (Platyhelminthes, Geoplanidae), on Menorca (Balearic Islands, Spain). ZooKeys 199:91-105.

Campbell JE, Gibson DJ. 2001. The effect of seeds of exotic species transported via horse dung on vegetation along trail corridors. Plant Ecology 157:23-35.

Cannon RJC, Baker RHA, Taylor MC, Moore JP. 1999. A review of the status of the New Zealand flatworm in the UK. Annals of Applied Biology 135(3):597-614.

Carbayo F, Leal-Zanchet AM, Vieira EM. 2002. Terrestrial flatworm (Platyhelminthes: Tricladida: Terricola) diversity versus man-induced disturbance in an ombrophilous forest in southern Brazil. Biodiversity and Conservation 11(6):1091-1104.

Carbayo F, Álvarez-Presas M, Olivares, CT, Marques FPL, Froehlich EM, Riutort M. 2013. Molecular phylogeny of Geoplaninae (Platyhelminthes) challenges current classification: proposal of taxonomic actions. Zoologica Scripta 42(5):508-528.

Carranza S, Littlewood DTJ, Clough KA, Ruiz-Trillo I, Baguñà J, Riutort M. 1998. A robust molecular phylogeny of the Tricladida (Platyhelminthes: Seriata) with a discussion on morphological synapomorphies. Proceedings of the Royal Society B: Biological Sciences 265(1396):631-640.

Darriba D, Taboada GL, Doallo R and Posada D. 2012. jModelTest 2: more models, new heuristics and parallel computing. Nature Methods 9(8):772.

DEFRA. 2005. Code of practice to prevent the spread of non-indigenous flatworms. Available at http://www.defra.gov.uk/planth/pestnote/flat.htm (accessed 28 March 2014).

Dehnen-Schmutz K, Holdenrieder O, Jeger MJ, Pautasso M. 2010. Structural change in the international horticultural industry: Some implications for plant health. Scientia Horticulturae 125:1-15.

DOVE. 2012. Code of Practice to Prevent the Spread of Non-Indigenous Flatworms. Dove Associates 17/01/2012.

Drew J, Anderson N, Andow D. 2010. Conundrums of a complex vector for invasive species control: a detailed examination of the horticultural industry. Biological Invasions 12:28372851.

Ducey PK, Noce S. 1998. Successful invasion of New York State by the terrestrial flatworm, Bipalium adventitium. Northeastern Naturalist 5(3):199-206.

EPPO. 2000a. Import requirements concerning Arthurdendyus triangulatus. EPPO Standard PM $1 / 3(1)$.

EPPO. 2000b. Nursery inspection, exclusion and treatment for Arthurdendyus triangulatus. EPPO Standard PM 1/4(1).

Faubel A. 2004. Fauna Europaea: Platyhelminthes, Tricladida, Terricola. Fauna Europaea version 1.1. Available at http://www.faunaeur.org (accessed 28 March 2014).

Fernández F, Lago D, Negrete L, Brusa F, Damborenea C, Noreña C. 2013. Presencia de Obama marmorata (Schultze \& Müller, 1857) SF Geoplaninae en la Península Ibérica. primer registro de este género para Europa. [abstract $n^{\circ}$ 6]. VI Jornadas del Departament de 
Biodiversidad y Biología Evolutiva (MNCN-CSIC)-2013:19. Available at http://www.ucm.es/data/cont/media/www/12049/LIbro Resumenes JsBBE-MNCN2013\%20\%281\%29.pdf (accessed 1may 2014).

Filella-Subirá E. 1983. Nota sobre la presència de la planària terestre Bipalium kewense Moseley, 1878 a Catalunya. Butlleti de la Institució Catalana d'Història Natural 49:151.

Froehlich CG. 1956. On the biology of land planarians. Boletim da Faculdade de Filosofia, Ciências e Letras da Universidade de São Paulo, Série Zoologia 20:263-271.

Hall TA. 1999. BioEdit: a user-friendly biological sequence alignment editor and analysis program for Windows 95/98/NT. Nucleic Acids Symposium Series 41:95-98.

Hijmans RJ, Cameron SE, Parra JL, Jones PG, Jarvis A. 2005. Very high resolution interpolated climate surfaces for global land areas. International Journal of Climatology 25(15):19651978.

Hill MA, Merickel F. 2011. A new state record of Bipalium adventitium Hyman, 1943 (Tricladida: Platyhelminthes) from Idaho, with a key to the species of Bipalium known to inhabit the United States. Journal of the Idaho Academy of Science 47(1):25-27.

Hogan RN, Dunne R. 1996. The distribution of the New Zealand flatworm Artioposthia triangulata (Dendy) in the Republic of Ireland. Irish Naturalist Journal 25(6):210-212.

Jarić I, Cvijanović G. 2012. The tens rule in invasion biology: measure of a true impact or our lack of knowledge and understanding?. Environmental Management 50:979-981.

Jones HD. 1988. The status and distribution of British terrestrial planarians. Progress in Zoology 36:511-516.

Jones HD. 1998. The African and European land planarian fauna, with an identification guide for field workers in Europe. Pedobiologia 42:477-489.

Jones HD. 2005. British land flatworms. British Wildlife 16:189-194.

Jones HD, Webster BL, Littlewood DTJ, McDonald JC. 2008. Molecular and morphological evidence for two new species of terrestrial planarians of the genus Microplana (Platyhelminthes; Turbellaria; Tricladida; Terricola) from Europe. Zootaxa 1945:1-38.

Jones HD, Johns PM, Winsor L. 1998. The proposed synonymy of Parakontikia ventrolineata (Dendy, 1892) and Kontikia mexicana (Hyman, 1939): what is a penis papilla? Hydrobiologia 383:91-96.

Justine JL, Winsor L, Gey D, Gros P, Thévenot J. 2014. The invasive New Guinea flatworm Platydemus manokwari in France, the first record for Europe: time for action is now. PeerJ 2:e297. DOI 10.7717/peerj.297.

Katoh K, Standley DM. 2013. MAFFT multiple sequence alignment software version 7: improvements in performance and usability. Molecular Biology and Evolution 30(4):772780 .

Lázaro EM, Sluys R, Pala M, Stocchino GA, Baguñà J, Riutort M. 2009. Molecular barcoding and phylogeography of sexual and asexual freshwater planarians of the genus Dugesia in the Western Mediterranean (Platyhelminthes, Tricladida, Dugesiidae). Molecular Phylogenetics and Evolution 52(3):835-845.

Lilleskov E, Callaham MA, Pouyat R, Smith JE, Castellano M, Gonzalez G, Lodge DJ, Arango R, Green F. 2010. Invasive soil organisms and their effects on belowground processes. In: Dix ME, Britton K, eds. A dynamic invasive species research vision: opportunities and priorities 2009-29. Washington DC: USDA Forest Service, Research and Development GTR WO-79/83, 67-83.

Mateos E, Cabrera C, Carranza S, Riutort M. 2009. Molecular analysis of the diversity of terrestrial planarians (Platyhelminthes, Tricladida, Continenticola) in the Iberian Peninsula. Zoologica Scripta 38(6):637-649. 
622

623

624

625

626

627

628

629

630

631

632

633

634

635

636

637

638

639

640

641

642

643

644

645

646

647

648

649

650

651

652

653

654

655

656

657

658

659

660

661

662

663

664

665

666

667

668

669

Mateos E, Giribet G, Carranza S. 1998. Terrestrial planarians (Platyhelminthes, Tricladida, Terricola) from the Iberian peninsula: first records of the family Rhynchodemidae, with the description of a new Microplana species. Contributions to Zoology 67(4):267-276.

Mateos E, Tudó A, Álvarez-Presas M, Riutort M. 2013. Planàries terrestres exòtiques a la Garrotxa. Annals de la Delegació de la Garrotxa de la ICHN 6:67-73.

McDonald JC, Jones HD. 2007. Abundance, reproduction, and feeding of three species of British terrestrial planarians: Observations over 4 years. Journal of Natural History 41(5-8):293312.

Mather JG, Christensen OM. 1992. The exotic land planarian Artioposthia triangulata in the Faroe Islands: colonization and habitats. Fródskaparrit 40:49-60.

Minelli, A. 1977. A taxonomic review of the terrestrial planarians of Europe. Bolletino di Zoologia 44:399-419.

National Research Council. 2002. Predicting invasions of nonindigenous plants and plant pests. Committee on the Scientific Basis for Predicting the Invasive Potential of Nonindigenous Plants and Plant Pests in the United States, National Research Council. Washington DC: The National Academies Press.

NNSS (Great Britain Non-Native Species Secretariat). 2013. Kontikia flatworms (Kontikia ventrolineata and andersoni). Available at http://www.nonnativespecies.org/downloadDocument.cfm?id=147. (accessed on 1 May 2014).

Ogren RE. 1985. The human factor in the spread of an exotic planarian in Pennsylvania. Proceedings of the Pennsylvania Academy of Science 59:117-118.

Ogren RE, Kawakatsu M. 1998. American Nearctic and Neotropical land planarian (Tricladida: Terricola) faunas. Pedobiologia 42:441-451.

Olewine DA. 1972. Further observations on the land planarians, Bipalium kewense and Geoplana vaga (Turbellaria: Tricladida: Terricola). Bulletin of the Association for Southeastern Biologists 19:88.

Phillips SJ, Anderson RP, Schapire RE. 2006. Maximum entropy modeling of species geographic distributions. Ecological Modelling 190(3-4):231-259.

Phillips SJ, Dudík M. 2008. Modeling of species distributions with Maxent: new extensions and a comprehensive evaluation. Ecography 31(2):161-175.

Richardson DM, Pyšek P, Rejmánek M, Barbour MG, Panetta FD, West CJ. 2000. Naturalization and invasion of alien plants: concepts and definitions. Diversity and Distributions 6(2):93107.

Ronquist F, Teslenko M, van der Mark P, Ayres DL, Darling A, Höhna S, Larget B, Liu L, Suchard MA, Huelsenbeck JP. 2012. MrBayes 3.2: efficient Bayesian inference and model choice across a large model space. Systematic Biology 61(3):539-542.

Roques A, Rabitsch W, Rasplus JY, Lopez-Vaamonde C, Nentwig W, Kenis M. 2009. Alien Terrestrial Invertebrates of Europe. In: DAISIE Handbook of alien species in Europe. Dordrecht: Springer, 63-79.

SEERAD. 2000. Biological and ecological studies of the New Zealand flatworm, Arthurdendyus triangulatus: Towards a comprehensive risk assessment for the UK. Final Report for the period 1st March 1997 to 31st March 2000. Central Science Laboratory Ministry of Agriculture, Fisheries and Food, Sand Hutton, York.

Sluys R, Kawakatsu M, Riutort M, Baguñà J. 2009. A new higher classification of planarian flatworms (Platyhelminthes, Tricladida). Journal of Natural History 43 (29-30):1763-1777.

Simberloff D, Martin JL, Genovesi P, Maris V, Wardle DA, Aronson J, Courchamp F, Galil B, García-Berthou E, Pascal M, Pysek P, Sousa R, Tabacchi E, Vilà M. 2013. Impacts of

PeerJ reviewing PDF | (v2014:04:2013:2:0:ACCEPTED 26 May 2014) 
biological invasions: what's what and the way forward. Trends in Ecology \& Evolution 28(1):58-66.

Stamatakis A. 2006. RAxML-VI-HPC: maximum likelihood-based phylogenetic analyses with thousands of taxa and mixed models. Bioinformatics 22(21):2688-2690.

Sugiura S. 2008. Hot water tolerance of soil animals: utility of hot water immersions for biological invasions of soil animals. Applied Entomology and Zoology 43:207-212.

Sunnucks P, Blacket MJ, Taylor JM, Sands CJ, Ciavaglia SA, Garrick RC, Tait NN, Rowell DM, Pavlova A. 2006. A tale of two flatties: different responses of two terrestrial flatworms to past environmental climatic fluctuations at Tallaganda in montane southeastern Australia. Molecular Ecology 15:4513-4531.

Terrace TE, Baker GH. 1994. The blue land planarian, Caenoplana coerulea Moseley (Tricladida: Geoplanidae), a predator of Ommatoiulus moreleti (Lucas) (Diplopoda: Julidae) in South Australia. Journal of the Entomologycal Society of Australia 33: 371-372.

Vilà M, Basnou C, Pysek P, Josefsson M, Genovesi P, Gollasch S, Nentwig W, Olenin S, Roques A, Roy D, Hulme PE, DAISIE partners. 2010. How well do we understand the impacts of alien species on ecosystem services? A pan-European, cross-taxa assessment. Frontiers in Ecology and the Environment. doi:10.1890/080083.

Vila-Farré M, Mateos E, Sluys R, Romero R. 2008. Terrestrial planarians (Platyhelminthes, Tricladida, Terricola) from the Iberian Peninsula: new records and description of three new species. Zootaxa 1739:1-20.

Vila-Farré M, Sluys R, Mateos E, Jones HD, Romero R. 2011. Land planarians (Platyhelminthes: Tricladida: Geoplanidae) from the Iberian Peninsula: new records and description of two new species, with a discussion on ecology. Journal of Natural History 45(15-16):869-891.

Wallner W. 1937. Rhynchodemus terrestris, eine Landplanarie. Blätter Aquarien und Terrarienkunde 48:224-227.

Williamson M, Fitter A. 1996. The varying success of invaders. Ecology 77(6):1661-1666.

Williamson M. 1996. Biological invasions. London: Chapman and Hall.

Williamson MH, Brown KC. 1986. The analysis and modelling of British invasions. Philosophical Transactions of the Royal Society of London B 314:505-522.

Winsor L, Johns PM, Yeates GW. 1998. Introduction, and ecological and systematic background, to the Terricola (Tricladida). Pedobiologia 42:389-404.

Winsor L, Johns PM, Barker GM. 2004. Terrestrial planarians (Platyhelminthes: Tricladida: Terricola) predaceous on terrestrial gastropods. In: Barker GM, ed. Natural Enemies of Terrestrial Molluscs. London: CAB International, 227-278. 


\section{Table 1 (on next page)}

Localities where introduced species have been found/recorded in the lberian Peninsula.

Data organized chronologically. Sampling code: (fs) specimens from field surveys conducted by us in gardens, nurseries and semi-natural areas, (sbp) specimens sent by people who knew our work through the information in social networks, (bd) bibliographic data. Date in format yyyy/mm/dd. Collectors: AG, Alberto Gayoso; AL, Álvaro Leal; AT, Àngels Tudó; CC, Cristina Cabrera; $\mathrm{Cl}$, César de Inés; CS, Carmen Soler; EM, Eduardo Mateos; GG,, Georgina Gratacós;IV, Iván Salvia; JM, Jacobo Martín; MR, Marta Riutort; RS, Roberto Sáez; VS, Vicent Sancho; Montilivi-WEB, http,/www.iesmontilivi.net/WebProfes/jbarbara/web/Galeria/Imatges/Invertebrats/cuc.htm; XB, Xavier Béjar. 


\begin{tabular}{|c|c|c|c|c|c|c|c|}
\hline $\begin{array}{l}\text { Sampling } \\
\text { code }\end{array}$ & Loc code & Locality & Position & Habitat & Species & Date & Collector/Ref \\
\hline bd & A & $\begin{array}{l}\text { Caldes d'Estrac } \\
\text { (Barcelona) }\end{array}$ & $\begin{array}{l}\text { N41.569467 } \\
\text { E2.526316 }\end{array}$ & garden & Bipalium kewense & 1983 & $\begin{array}{l}\text { Filella-Subirá } \\
1983\end{array}$ \\
\hline fs & B & $\begin{array}{l}\text { Bartelona } \\
\text { (Ba) }\end{array}$ & $\begin{array}{l}\text { N41.398539 } \\
\text { E2.142162 }\end{array}$ & garden & Bipalium kewense & 1995 & $\mathrm{MR}$ \\
\hline sbp & C & $\begin{array}{l}\text { Loumizan } \\
\text { (Pontevedra) }\end{array}$ & $\begin{array}{l}\text { N42.410111 } \\
\text { W8.667716 }\end{array}$ & nursery & Bipalium kewense & 1990 & AG \\
\hline $\mathrm{bd}$ & $\mathrm{D}$ & $\begin{array}{l}\text { Girâna } \\
\text { (Girona) }\end{array}$ & $\begin{array}{l}\text { N41.964541 } \\
\text { E2.827842 }\end{array}$ & garden & Bipalium kewense & 1994 & Montilivi-WEB \\
\hline sbp & $\mathrm{E}$ & $\begin{array}{l}\text { Vilqamalea } \\
\text { (Alsacete) }\end{array}$ & $\begin{array}{l}\text { N39.362159 } \\
\text { W1.601281 }\end{array}$ & nursery & Bipalium kewense & 1998 & VS \\
\hline sbp & $\mathrm{F}$ & $\begin{array}{l}\text { Bétera } \\
\text { (Varència) }\end{array}$ & $\begin{array}{l}\text { N39.604153 } \\
\text { W0.507864 }\end{array}$ & garden & Bipalium kewense & 1999 & VS \\
\hline $\mathrm{bd}$ & G & $\begin{array}{l}\text { Bencarmargosa } \\
\text { (Málaga) }\end{array}$ & $\begin{array}{l}\text { N36.8248 } \\
\text { W4.1809 }\end{array}$ & $\begin{array}{l}\text { mango } \\
\text { plantation }\end{array}$ & Rhynchodemini Ri1 ${ }^{G}$ & $2007 / 12 / 25$ & $\begin{array}{l}\text { Vila-Farré et al. } \\
2011 \\
\text { as Platydemus sp }\end{array}$ \\
\hline $\mathrm{sbp}$ & $\mathrm{H}$ & $\begin{array}{l}\text { Ba alona } \\
\text { (Bricelona) }\end{array}$ & $\begin{array}{l}\text { N41.460177 } \\
\text { E2.243985 }\end{array}$ & garden & Caenoplana Cal ${ }^{\mathrm{G}}$ & 2008 & $\mathrm{RS}$ \\
\hline $\mathrm{bd}$ & I & $\begin{array}{l}\text { Merca } \\
\text { (IDearic Islands) }\end{array}$ & $\begin{array}{l}\text { N39.95000 } \\
\text { E3.850000 }\end{array}$ & orchard & Caenoplana coerulea & $2009 / 04$ & $\begin{array}{l}\text { Breugelmans et al. } \\
2012\end{array}$ \\
\hline fs & $\mathrm{J}$ & $\begin{array}{l}\text { Torruella de } \\
\text { Fluvià } \\
\text { (Girona) }\end{array}$ & $\begin{array}{l}\mathrm{N} 42.17559 \\
\mathrm{E} 3.03953\end{array}$ & garden & Obama sp. $6^{\mathrm{G}}$ & $2010 / 04 / 04$ & $\mathrm{MR}$ \\
\hline sbp & $\mathrm{K}$ & $\begin{array}{l}\text { Òliva } \\
\text { (Valencia) }\end{array}$ & $\begin{array}{l}\text { N38.910550 } \\
\text { W0.073200 }\end{array}$ & garden & Caenoplana Cal ${ }^{G}$ & $2010 / 11 / 08$ & VS \\
\hline sbp & $\mathrm{L}$ & $\begin{array}{l}\text { Ames } \\
\text { (A Coruña) }\end{array}$ & $\begin{array}{l}\text { N42.857955 } \\
\text { W8.653278 }\end{array}$ & garden & Caenoplana Cal & $2010 / 12 / 10$ & $A G$ \\
\hline fs & $\mathrm{M}$ & $\begin{array}{l}\text { Granollers } \\
\text { (Barcelona) }\end{array}$ & $\begin{array}{l}\text { N41.570240 } \\
\mathrm{E} 2.270532\end{array}$ & semi-natural & $\begin{array}{l}\text { Caenoplana Cal }{ }^{G} \\
\text { Kontikia } \\
\text { ventrolineata }^{G}\end{array}$ & $\begin{array}{l}2011 / 02 / 28 \\
2012 / 10 / 12\end{array}$ & $\begin{array}{l}\text { CS } \\
\text { EM }\end{array}$ \\
\hline sbp & $\mathrm{N}$ & $\begin{array}{l}\text { Boadilla del Campo } \\
\text { (Madrid) }\end{array}$ & $\begin{array}{l}\text { N40.405270 } \\
\text { W3.877014 }\end{array}$ & garden & Caenoplana $\mathrm{Ca} 1$ & $2011 / 10 / 15$ & $\mathrm{JM}$ \\
\hline fs & O & $\begin{array}{l}\text { El Prat de } \\
\text { Llobregat } \\
\text { (Barcelona) }\end{array}$ & $\begin{array}{l}\text { N41.309519 } \\
\mathrm{E} 2.120887\end{array}$ & semi-natural & Caenoplana Cal GM & $2011 / 11 / 05$ & $\mathrm{EM} \& \mathrm{CC}$ \\
\hline fs & $\mathrm{P}$ & $\begin{array}{l}\text { Vall d'en Bas } \\
\text { (Girona) }\end{array}$ & $\begin{array}{l}\text { N42.125939 } \\
\mathrm{E} 2.433678\end{array}$ & semi-natural & $\begin{array}{l}\text { Caenoplana Cal G } \\
\text { Rhynchodemus Rs1 Gм }\end{array}$ & $\begin{array}{l}2011 / 11 / 12 \\
2011 / 11 / 26\end{array}$ & 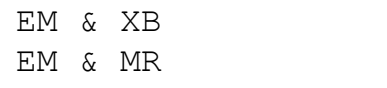 \\
\hline
\end{tabular}




\begin{tabular}{|c|c|c|c|c|c|c|c|c|}
\hline fs & $\mathrm{Q}$ & $\begin{array}{l}\text { Gavà-1 } \\
\text { (Barcelona) }\end{array}$ & $\begin{array}{l}\mathrm{N} 41.288100 \\
\mathrm{E} 2.006233\end{array}$ & nursery & Obama sp & 2012/03/13 & $A T \& 1$ & MR \\
\hline fs & $\mathrm{R}$ & $\begin{array}{l}\text { Gavà-2 } \\
\text { (Barcelona) }\end{array}$ & $\begin{array}{l}\mathrm{N} 41.293222 \\
\mathrm{E} 2.017583\end{array}$ & nursery & Obama sp ${ }^{G}$ & 2012/03/14 & $\mathrm{AT} \& \mathrm{I}$ & MR \\
\hline fs & $\mathrm{s}$ & $\begin{array}{l}\text { Vilassar de Mar } \\
\text { (Barocelona) }\end{array}$ & $\begin{array}{l}\text { N41.497084 } \\
\text { E2.376178 }\end{array}$ & nursery & Obama sp ${ }^{G}$ & $2012 / 03 / 28$ & $\mathrm{AT} \& \mathrm{I}$ & MR \\
\hline fs & $\mathrm{T}$ & $\begin{array}{l}\text { Tortosa } \\
\text { (Tacragona) }\end{array}$ & $\begin{array}{l}\text { N40.767329 } \\
\text { E0.556963 }\end{array}$ & nursery & Obama sp ${ }^{G}$ & 2012/04/04 & $\mathrm{AT}$ & \\
\hline sbp & $\mathrm{U}$ & $\begin{array}{l}\text { Treto } \\
\text { (Cantabria) }\end{array}$ & $\begin{array}{l}\text { N43.392385 } \\
\text { W3.470387 }\end{array}$ & garden & $\begin{array}{l}\text { Obama sp }{ }^{G} \\
\text { Bipalium kewense }{ }^{G}\end{array}$ & 2012/06/27 & CI & \\
\hline fs & $\mathrm{V}$ & 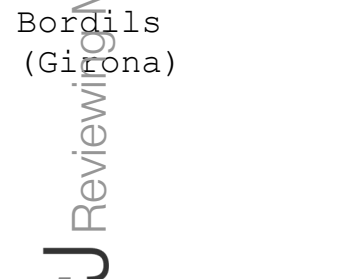 & $\begin{array}{l}\mathrm{N} 42.034804 \\
\mathrm{E} 2.898615\end{array}$ & nursery & $\begin{array}{l}\text { Caenoplana Cal G } \\
\text { Caenoplana Ca2 GM } \\
\text { Caenoplana bicolor } \\
\text { Obama sp } \\
\text { Dolychoplana } \\
\text { striata } \\
\text { Bipalium kewense }\end{array}$ & 2012/10/22 & EM & \\
\hline sbp & $\mathrm{W}$ & $\begin{array}{l}\text { Gi no } \\
\text { (Gdi) }\end{array}$ & $\begin{array}{l}\mathrm{N} 42.009800 \\
\mathrm{E} 2.825554\end{array}$ & garden & Caenoplana coerulea & $2013 / 09 / 11$ & GG & \\
\hline stop & $\mathrm{X}$ & $\begin{array}{l}\text { Polop } \\
\text { (Alicante) }\end{array}$ & $\begin{array}{l}\text { N38.622149 } \\
\text { W0.126626 }\end{array}$ & garden & Caenoplana coerulea & 2014/02/01 & $\mathrm{AL}$ & \\
\hline sbp & $\mathrm{Y}$ & $\begin{array}{l}\text { Cártama } \\
\text { (Málaga) }\end{array}$ & $\begin{array}{l}\text { N36.748333 } \\
\text { W4.586944 }\end{array}$ & garden & Obama sp & 2014/03/01 & IV & \\
\hline
\end{tabular}

${ }^{\mathrm{G}}$ species with genetic sequences; ${ }^{\mathrm{M}}$ species sectioned for internal anatomy study (see Table 2). 


\section{Table 2 (on next page)}

Sequenced specimens.

To each new sequence a three digits numeric code was assigned. Sequences from the GenBank database do not have specimen code number, only when there are more specimens from the same species in the same locality a specimen code was assigned (three letters+one number). Loc code as in Table 1. Collector: DB, Dani Boix; EM, Eduardo Mateos; HJ, Hugh Jones; KA, Miquel Arnedo; LL, Laia Leria; LW, L.Winsor; MA, Marta ÁlvarezPresas; SG, S.Graham; MV Miquel Vila. 
South Korea /GenBank Direct submission 2010-may-18

Japan / Alvarez-Presas et al. 2008

Vall d'en Bas (Girona, Spain) / Mateos et al. 2009

Canyamars (Barcelona, Spain) / Mateos et al. 2009

Pontedeume (A Coruña, Spain) / Mateos et al. 2009

Wainui Barrys Bay (New Zealand) / Alvarez-Presas et al. 2008

Australia / Baguñà et al. 2001 - Alvarez-Presas et al. 2008

Malborough (Australia) / Baguñà et al. 2001 - Alvarez-Presas et al. 2008

New Plymouth, Omata (New Zealand) / Alvarez-Presas et al. 2008

- / Alvarez-Presas et al. 2008

- / Alvarez-Presas et al. 2008

Bordils (Girona, Spain) / V*

New Plymouth, Omata (New Zealand) / Alvarez-Presas et al. 2008

Menorca (Balearic islands, Spain) / Breugelmans et al. 2012

Tallaganda (Australia) / Sunnucks et al. 2006

Victoria (Australia) / Sunnucks et al. 2006

El Prat de Llobregat (Barcelona, Spain) / O*
DQ665959 ${ }^{\mathrm{a}} \quad \mathrm{AF} 178307^{\mathrm{a}, \mathrm{c}}$

DQ665956 ${ }^{\mathrm{a}} \quad \mathrm{AF} 178306^{\mathrm{a}, \mathrm{c}}$

KJ599731 a $\quad$ KJ659612*a,c

KJ659703*a $\quad \mathrm{KJ} 659609 * \mathrm{a,c}$

$\mathrm{KJ} 659610 * \mathrm{a,c}$

$\mathrm{KJ} 659611^{* \mathrm{a}, \mathrm{c}}$

HM346600

HM346598

DQ666048

KJ599722 a $\quad$ FJ969947 a,c

KJ599721 a ${ }^{\text {a }} \quad$ FJ969964 ${ }^{\mathrm{a}, \mathrm{c}}$

KJ599724 a FJ969952 a,c

\begin{tabular}{|c|c|}
\hline DO665953a & DO666027 a,b,c \\
\hline DQ665954 ${ }^{\mathrm{a}}$ & AF $178325^{a, b, d}$ \\
\hline DQ665952a & $\mathrm{AF} 178305^{\mathrm{a}, \mathrm{b}}$ \\
\hline DQ665955 ${ }^{\mathrm{a}}$ & DQ666028 a,b,d \\
\hline DQ665964 ${ }^{\mathrm{a}}$ & DQ666031 a,b,d \\
\hline & DQ666032 \\
\hline KJ659705*a & KJ659648*a,b \\
\hline DQ665961 ${ }^{\mathrm{a}}$ & DQ666030 $0^{\mathrm{a}, \mathrm{b}}$ \\
\hline & JQ514564 $4^{\mathrm{a}, \mathrm{b}}$ \\
\hline & DO22762 ${ }^{b}$ \\
\hline & DQ227625 \\
\hline & DQ227627 ${ }^{b}$ \\
\hline & DQ227629 \\
\hline & DQ227631 \\
\hline & DQ227632 ${ }^{b}$ \\
\hline & DQ227633 $3^{a, b}$ \\
\hline & DQ227635 \\
\hline & DQ465372 a,b \\
\hline & KJ659613*a,b \\
\hline & \\
\hline
\end{tabular}




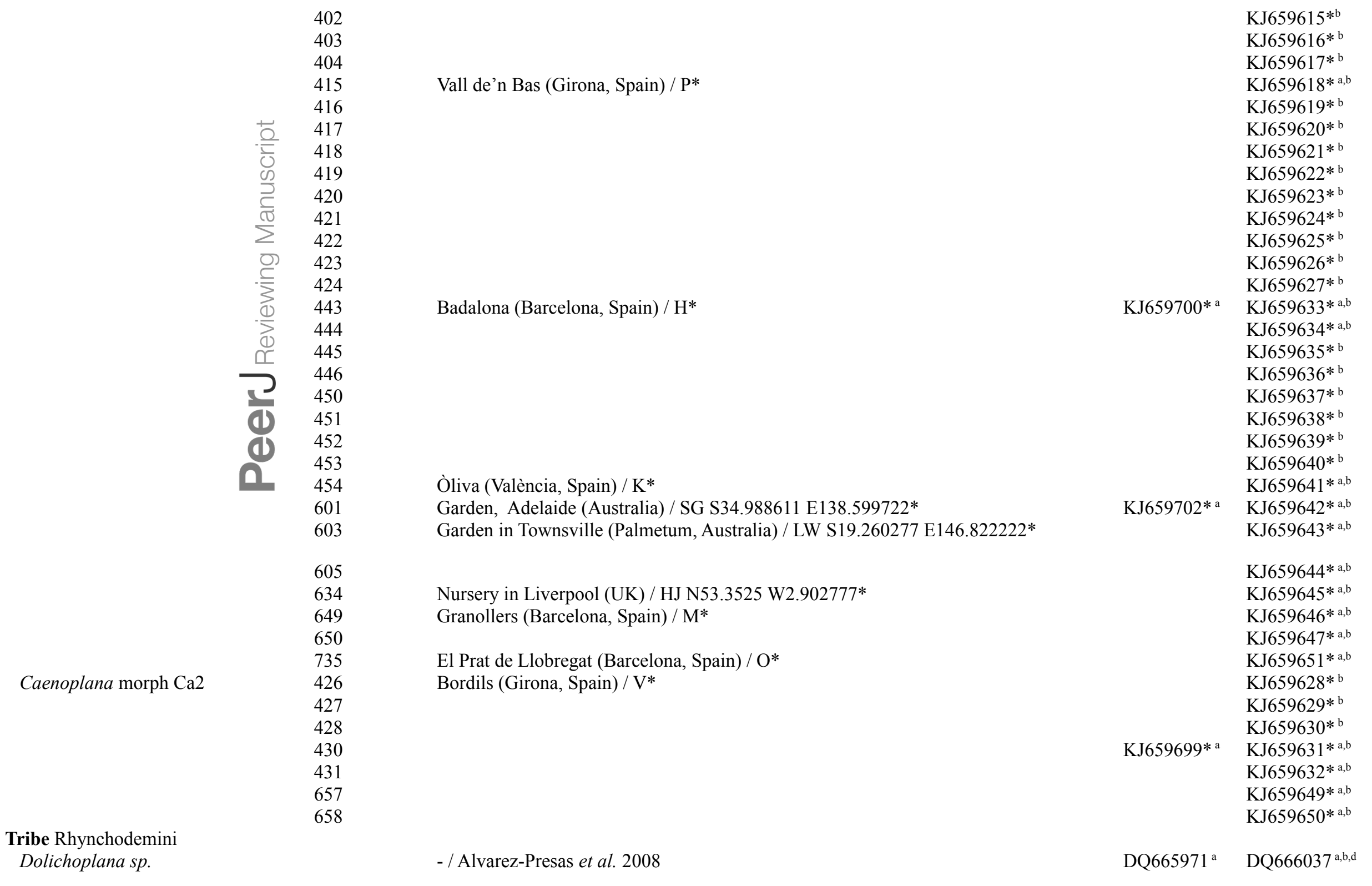


D. striata

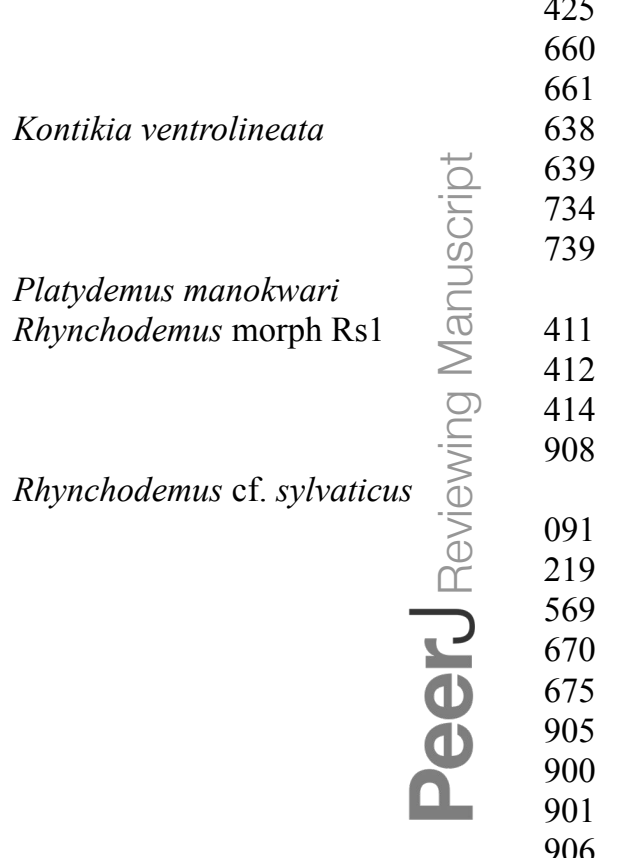

Rhynchodemini morph Ril

Rhynchodemini sp2

Rhynchodemini sp3

Subfamily Geoplaninae

Cratera crioula

C. tamoia

Obama sp.6

Obama sp.
Igreginha (Brazil) / Carbayo et al. 2013

Bordils (Girona, Spain) / V*

Granollers (Barcelona, Spain) / $\mathrm{M}^{*}$

Nursery in Liverpool (UK) / HJ N53.3525 W2.902777*

Saint Pée sur Nivelle (France) / MA N43.34235 W1.52650*

Townsville (Australia) / Baguñà et al. 2001 - Alvarez-Presas et al. 2008

Vall de'n Bas (Girona, Spain) / P*

Luarca, Asturias (Spain) / LL 4332'30.81"N 6³2'7.42"O*

Canyamars (Barcelona, Spain) / Mateos et al. 2009

Canyamars (Barcelona, Spain) / EM N41.598317 E2.44302*

Montjuich (Barcelona, Spain) / Vila-Farré et al. 2008 *

Underbarrow (UK) / N54.31776 W2.80783*

Pont en Royans (France) / N45.037875 E5.377033*

Benamargosa (Málaga, Spain) / Vila-Farré et al. 2011*

Sueiro, Asturias (Spain) / LL N43.527130 W6.877329*

Aljezur (Portugal) / LL N 37.316146 W8.803392*

Benamargosa (Málaga, Spain) / Vila-Farré et al. 2011 *

Benamargosa (Málaga, Spain) / Vila-Farré et al. 2011 *

Benamargosa (Málaga, Spain) / Vila-Farré et al. 2011 *

Benamargosa (Málaga, Spain) / Vila-Farré et al. 2011 *

Int. Park la Amistad, Pila (Panamá) / KA N8.524944 W82.618777*

São Paulo (Brazil) / Carbayo et al. 2013

Teresópolis (Brazil) / Carbayo et al. 2013

Paulo Lopes (Brazil) / Carbayo et al. 2013

Bordils (Girona, Spain) / V*

Gavà (Barcelona, Spain) / Q*
KC608341 a $\quad$ KC608226 a,b, $^{\text {a }}$

KJ659698*a KJ659679*a,

$\mathrm{KJ} 659683 *$ a,d

KJ659684*a,d

KJ659681*a,d

KJ659704*a KJ659682*a,d

$\mathrm{KJ} 659687^{* a, d}$

KJ599732 a $\quad$ KJ659688*a,d

DQ665986 a $\quad$ AF178320 a,b,d

KJ659697*a KJ659676*a,d

$\mathrm{KJ} 659677^{* a, d}$

KJ659678*a,d

KJ659696*d

FJ969946 a,b,d

KJ659672*d

$\mathrm{KJ} 659673^{* \mathrm{~d}}$

KJ659680*d

KJ659685*d

KJ659706*a KJ659686*d

KJ659694*d

KJ659689*d

$\mathrm{KJ} 659690^{* \mathrm{~d}}$

KJ659695*d

$\mathrm{KJ} 659691 * \mathrm{~d}$

KJ659692*

KJ659693*d

KJ659674*d

KJ659675*d

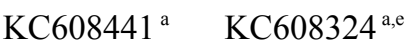

$\mathrm{KC}^{2} 68369^{\mathrm{a}} \quad \mathrm{KC} 608254^{\mathrm{a}, \mathrm{e}}$

$\mathrm{KC}^{2} 68425^{\mathrm{a}} \quad \mathrm{KC} 608308^{\mathrm{a}, \mathrm{e}}$

$\mathrm{KC} 08426^{\mathrm{a}} \mathrm{KC}^{\mathrm{N}} 68309^{\mathrm{a}, \mathrm{e}}$

KJ659652*a,e

$\mathrm{KJ} 659653 *$ a,e

KJ659654*a,e

KJ659663* a,e

KJ659664*a,e

$\mathrm{KJ} 659655^{* \mathrm{a}, \mathrm{e}}$ 


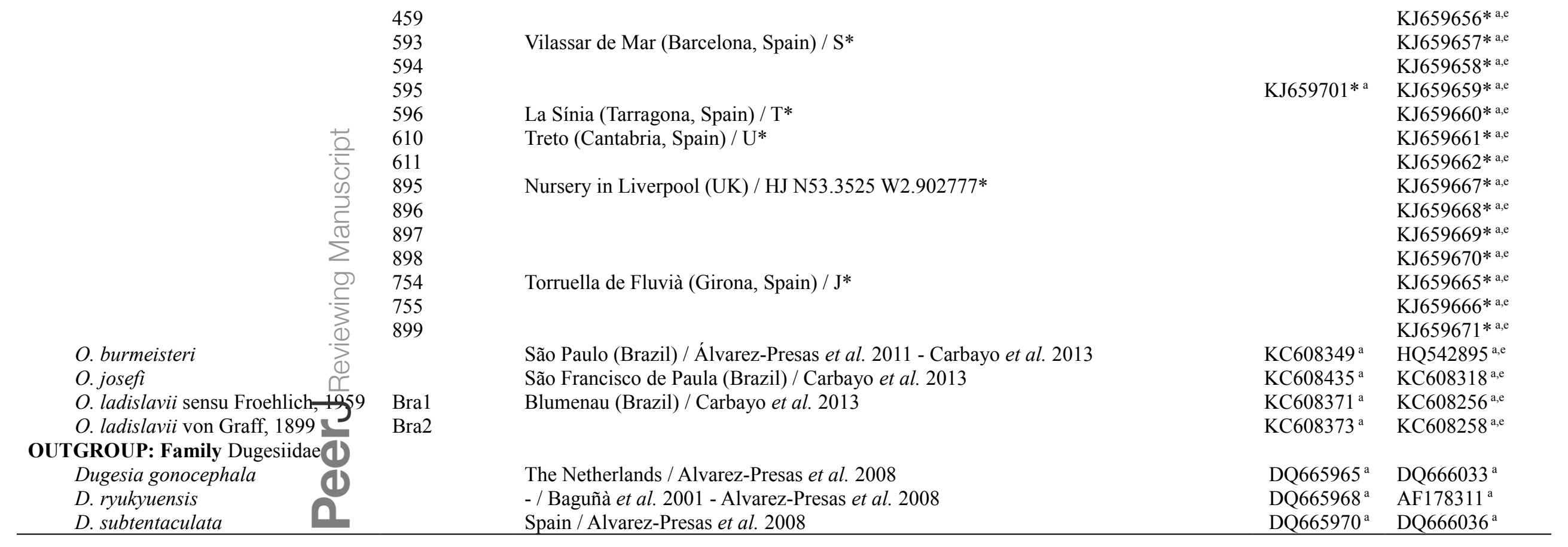

a,b,c,d,e a: Concatenated Dataset; b: Caenoplanini Dataset; c: Bipaliinae Dataset; d: Rhynchodemini Dataset; e: Geoplaninae Dataset *Sequences obtained in this study 


\section{Table 3 (on next page)}

Feeding habits of the introduced terrestrial flatworm species in the Iberian Peninula.

Native region sensu Winsor et al 2004. 


\begin{tabular}{|c|c|c|}
\hline $\begin{array}{l}\text { Species } \\
\text { (native region) }\end{array}$ & Prey & Reference \\
\hline $\begin{array}{l}\text { Bipalium kewense } \\
\text { (Vietnam to Kampuchea, } \\
\text { possibly extending to } \\
\text { Malaysia) }\end{array}$ & earthworms & See Winsor, Johns \& Barker, 2004 for refs \\
\hline $\begin{array}{l}\text { Caenoplana coerulea } \\
\text { (Eastern Australia) }\end{array}$ & $\begin{array}{l}\text { gastropods, arthropods, earthworms } \\
\text { isopods, diplopods, earwings } \\
\text { Ommatoiulus moreletii (diplopod) } \\
\text { beetles } \\
\text { diptera larvae }\end{array}$ & $\begin{array}{l}\text { See Winsor, Johns \& Barker, } 2004 \text { for refs } \\
\text { Olewine, } 1972 \\
\text { Terrace \& Baker, } 1994 \\
\text { Mateos et al., } 2013 \\
\text { Barnwell, } 1978\end{array}$ \\
\hline $\begin{array}{l}\text { Caenoplana bicolor } \\
\text { (unknown) }\end{array}$ & isopods & $\begin{array}{l}\text { Observations on captive } \\
\text { specimen by H.D. Jones }\end{array}$ \\
\hline $\begin{array}{l}\text { Caenoplana C02 } \\
\text { (unknown) }\end{array}$ & unknown & - \\
\hline $\begin{array}{l}\text { Dolichoplana striata } \\
\text { (Indo-Malay region) }\end{array}$ & earthworms & See Winsor, Johns \& Barker, 2004 for refs \\
\hline $\begin{array}{l}\text { Kontikia ventrolineata } \\
\text { (Queensland, Australia) }\end{array}$ & $\begin{array}{l}\text { gastropods, isopods } \\
\text { snails, slugs, hawkmoth caterpillars } \\
\text { isopods } \\
\text { isopods } \\
\text { earthworms }\end{array}$ & $\begin{array}{l}\text { See Winsor, Johns \& Barker, } 2004 \text { for refs } \\
\text { NNSS } 2013 \\
\text { Froehlich, } 1956 \\
\text { Olewine, } 1972 \\
\text { Present study }\end{array}$ \\
\hline $\begin{array}{l}\text { Obama } \\
\text { (Brazil*) }\end{array}$ & mollusks, earthworms & Fernando Carbayo (Personal communication) \\
\hline $\begin{array}{l}\text { Rhynchodemini Ri1 } \\
\text { (unknown) }\end{array}$ & unknown & - \\
\hline \multirow{2}{*}{$\begin{array}{l}\text { Rhynchodemus Rs1 } \\
\text { (unknown) }\end{array}$} & unknown & \\
\hline & $\begin{array}{l}\text { for Rhynchodemus [genus]: } \\
\text { springtails } \\
\text { springtails } \\
\text { springtails } \\
\text { woodlice }\end{array}$ & $\begin{array}{l}\text { Wallner, } 1937 \\
\text { Froehlich, } 1956 \\
\text { Ogren, } 1985 \\
\text { Jones, 2005 }\end{array}$ \\
\hline
\end{tabular}

* sensu Carbayo et al. 2013 


\section{Figure 1}

Distribution map of the terrestrial flatworms.

A, subfamily Bipaliinae. B, subfamily Geoplaninae. Information from http://turbellaria.umaine.edu. 


\section{Bipaliinae}

A

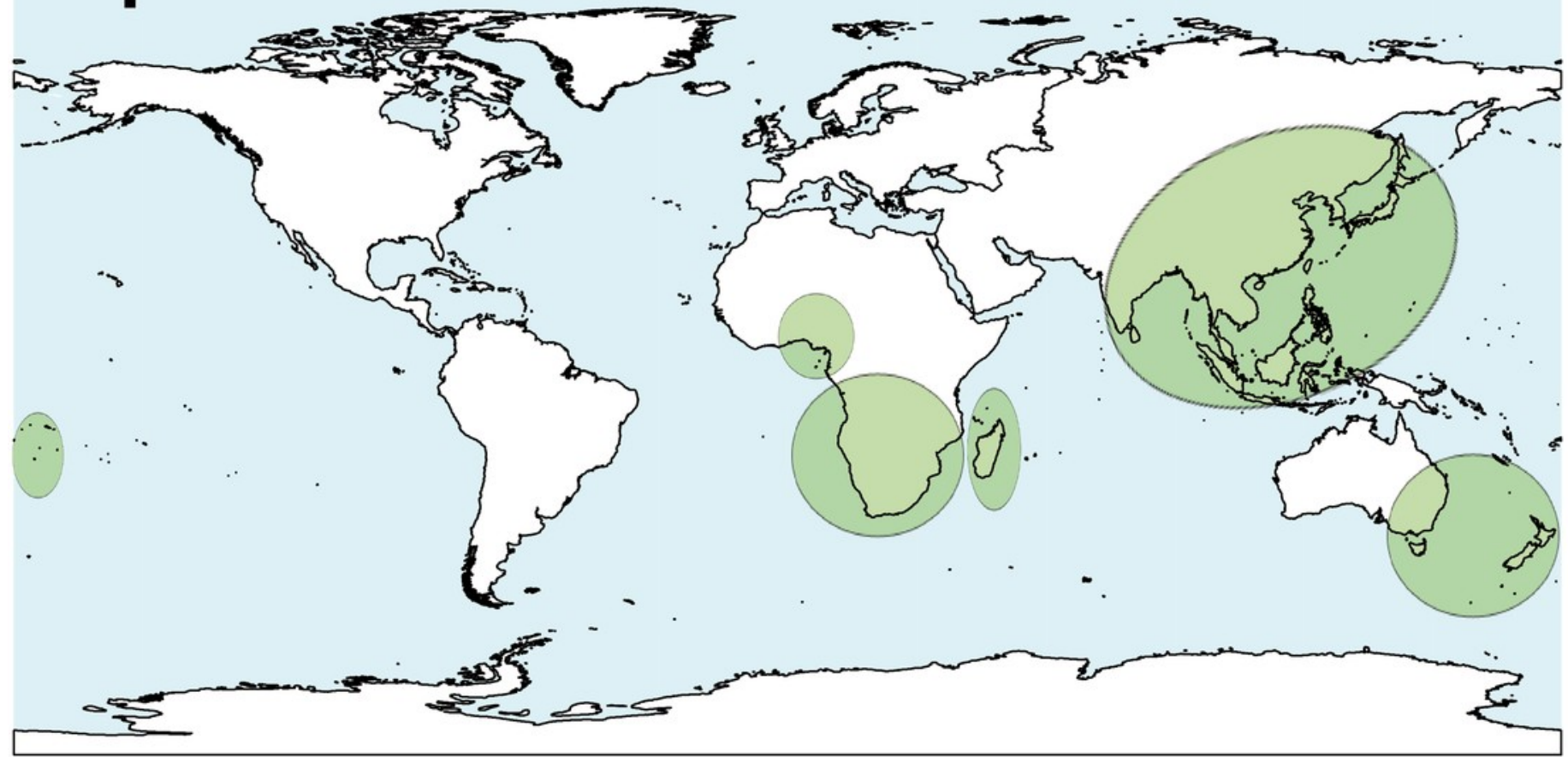

\section{Geoplaninae}

B

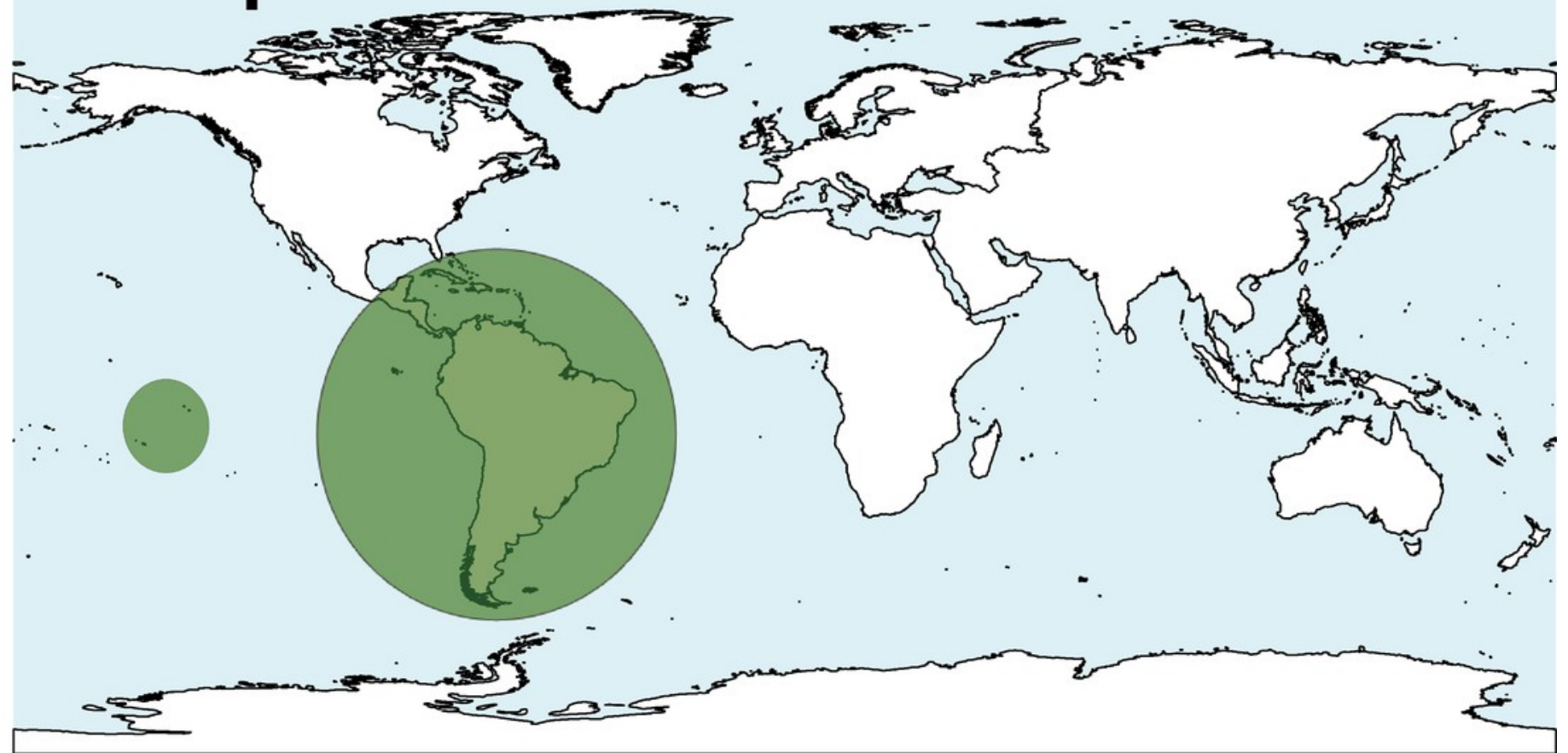




\section{Figure 2}

Distribution map of the terrestrial flatworms.

A, subfamily Microplaninae. B, subfamily Rhynchodeminae. Information from http://turbellaria.umaine.edu. 


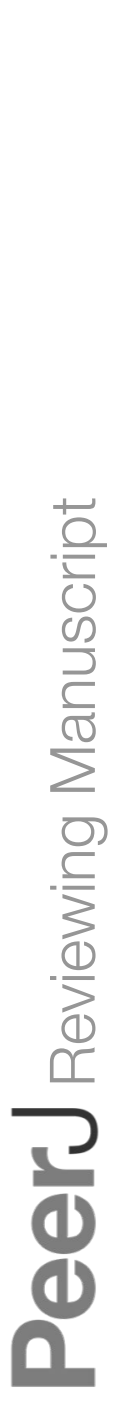

\section{Microplaninae}

A

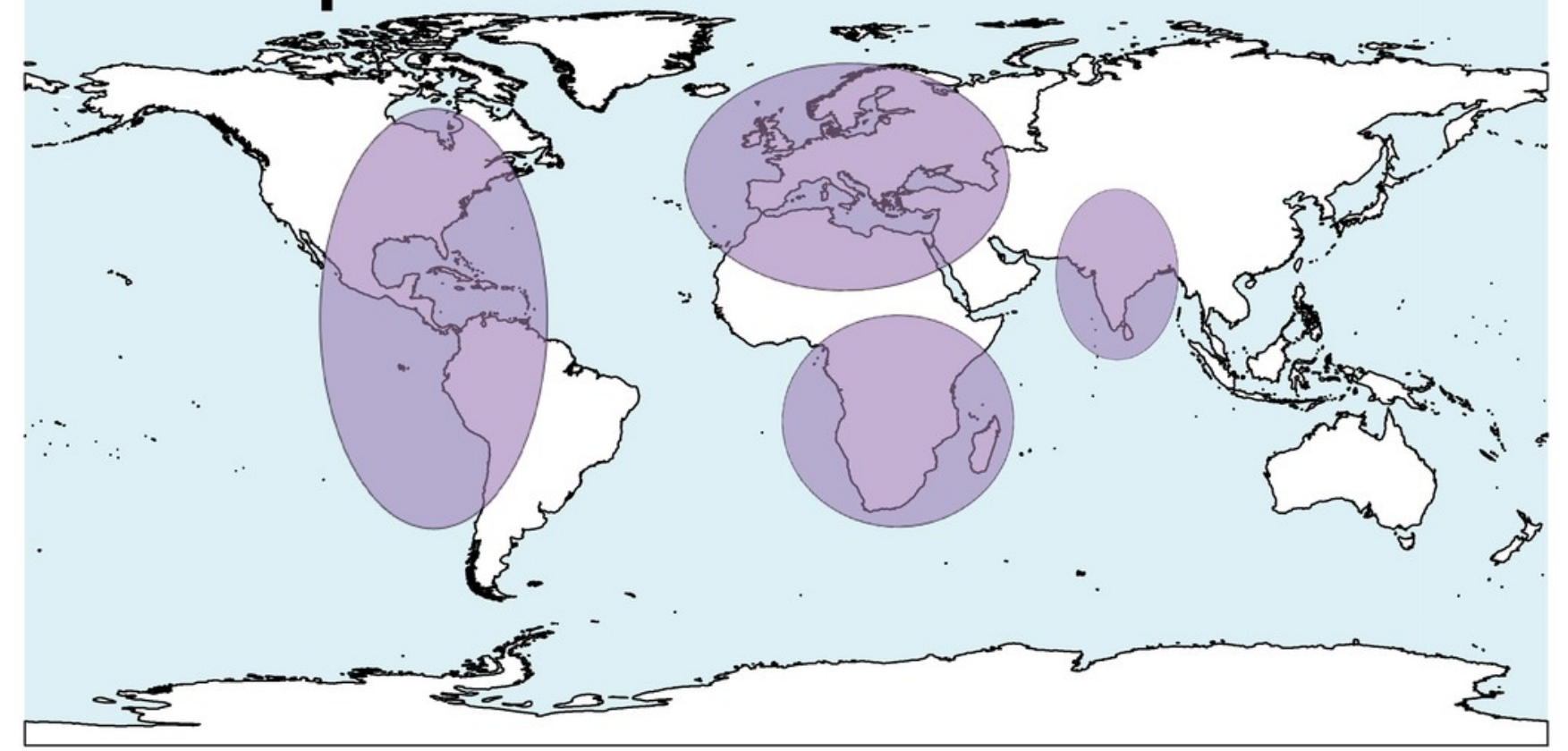

\section{Rhynchodeminae}
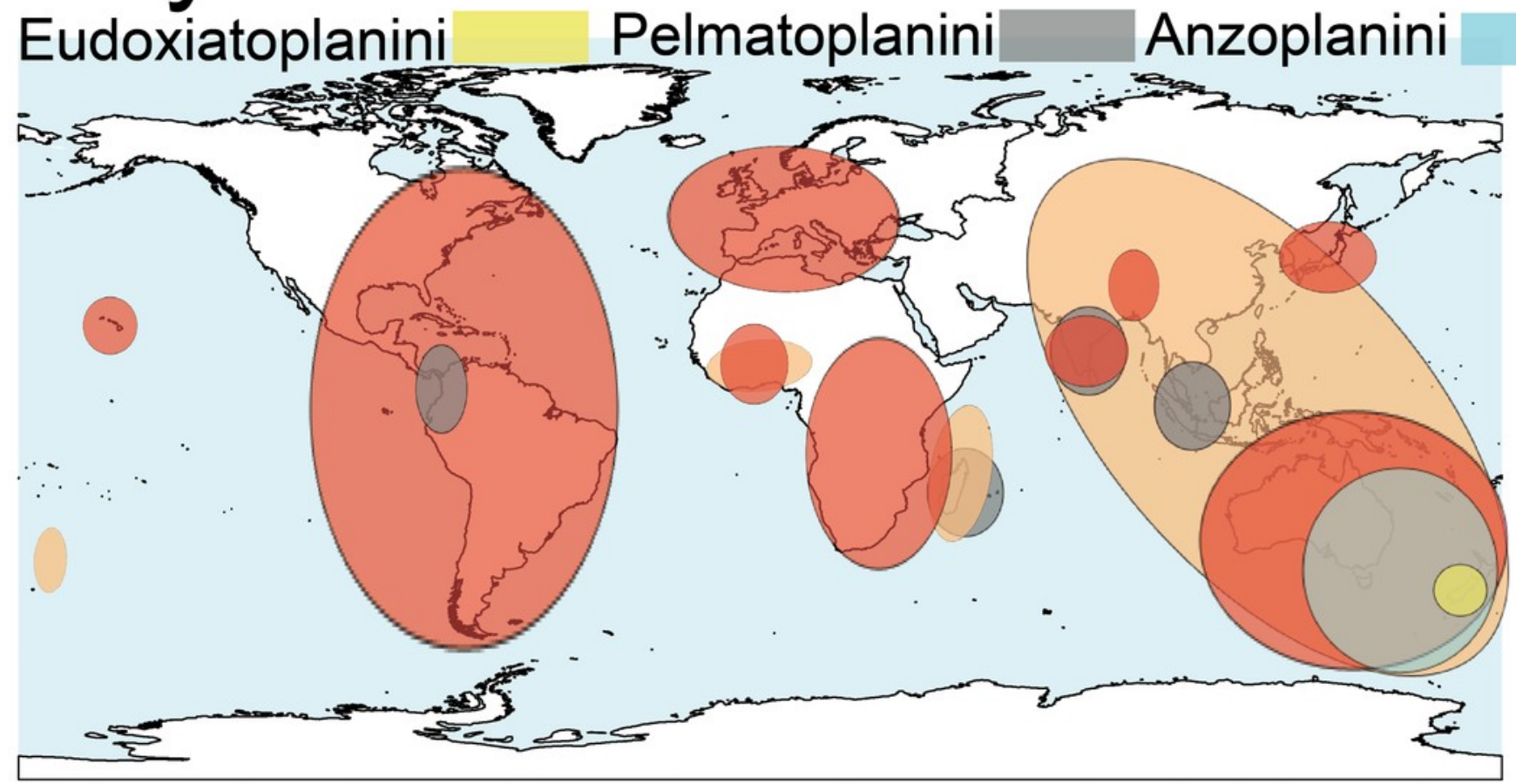

Rhynchodemini

Caenoplanini 


\section{Figure 3}

Distribution of sampling localities of introduced terrestrial flatworms in the lberian Peninsula.

Locality codes correspond to those in Table 1.

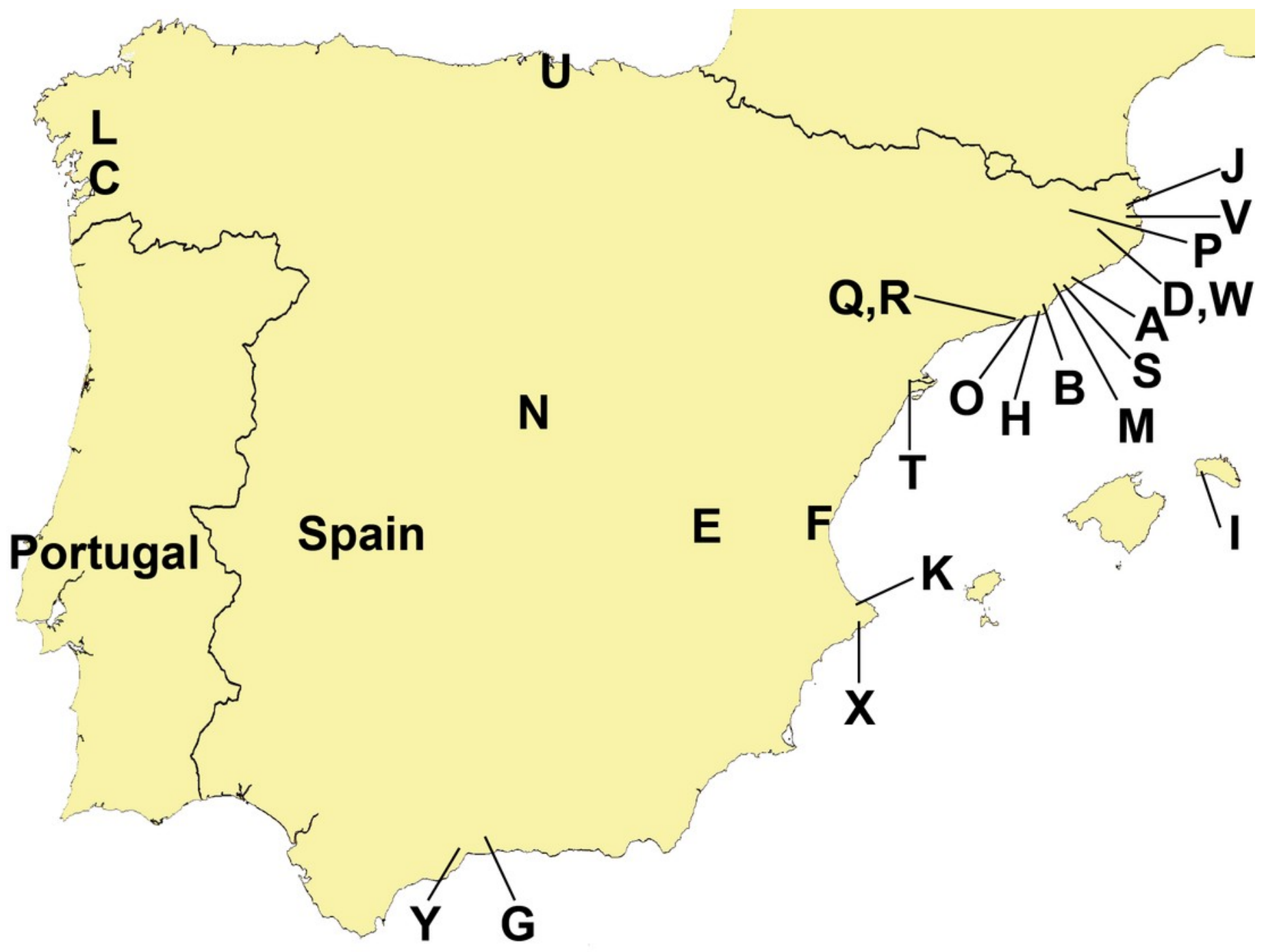




\section{Figure 4}

\section{Bipalium kewense.}

A, dorsal view. B, ventral view of median part. C, dorsal view of posterior end. $D$, dorsal view of anterior end. Scale bar $5 \mathrm{~mm}$.

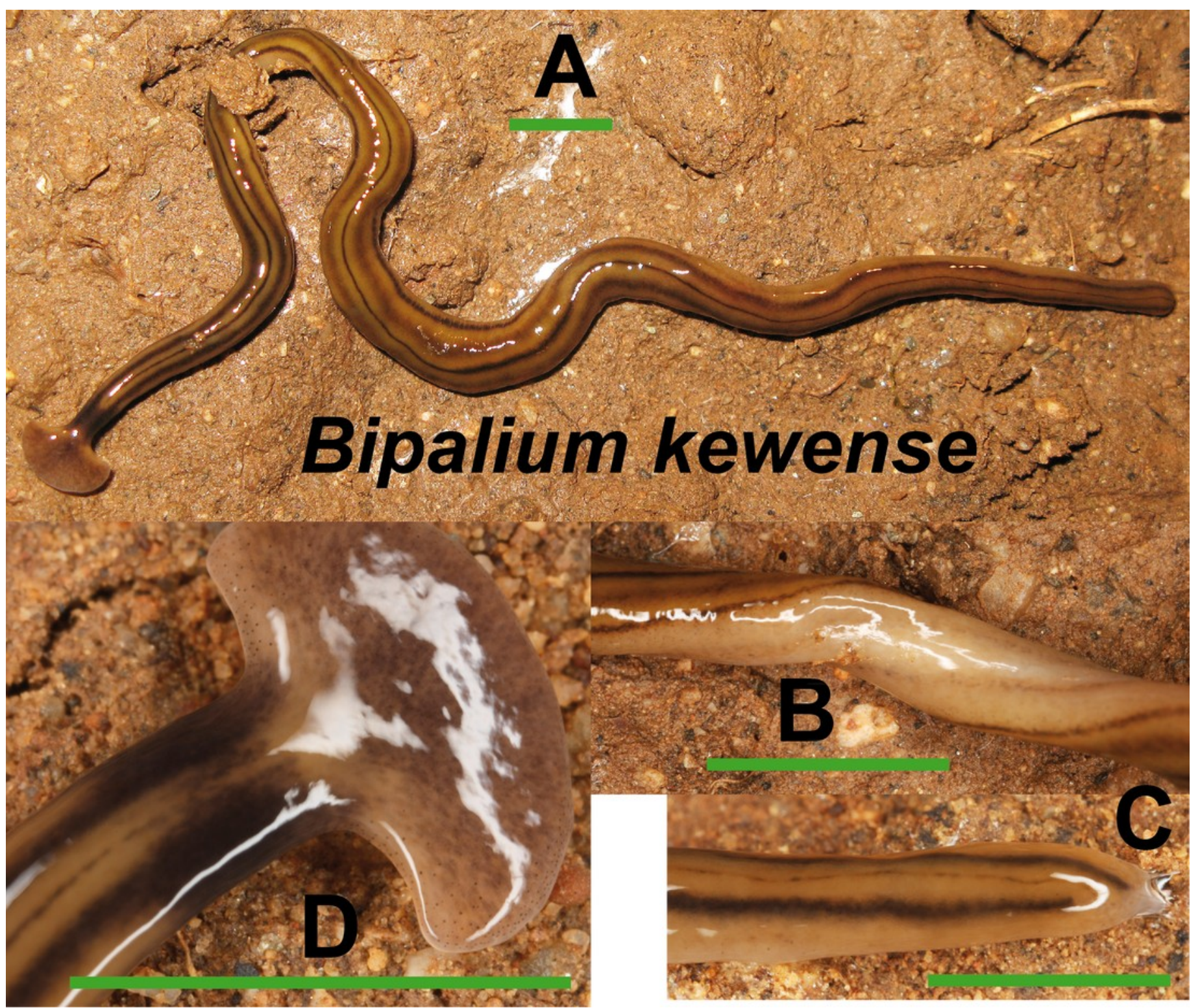




\section{Figure 5}

Caenoplana bicolor.

Dorsal view with partial ventral view in the center. The anterior end is not show (the specimen was damaged in this region). Scale bar $5 \mathrm{~mm}$.

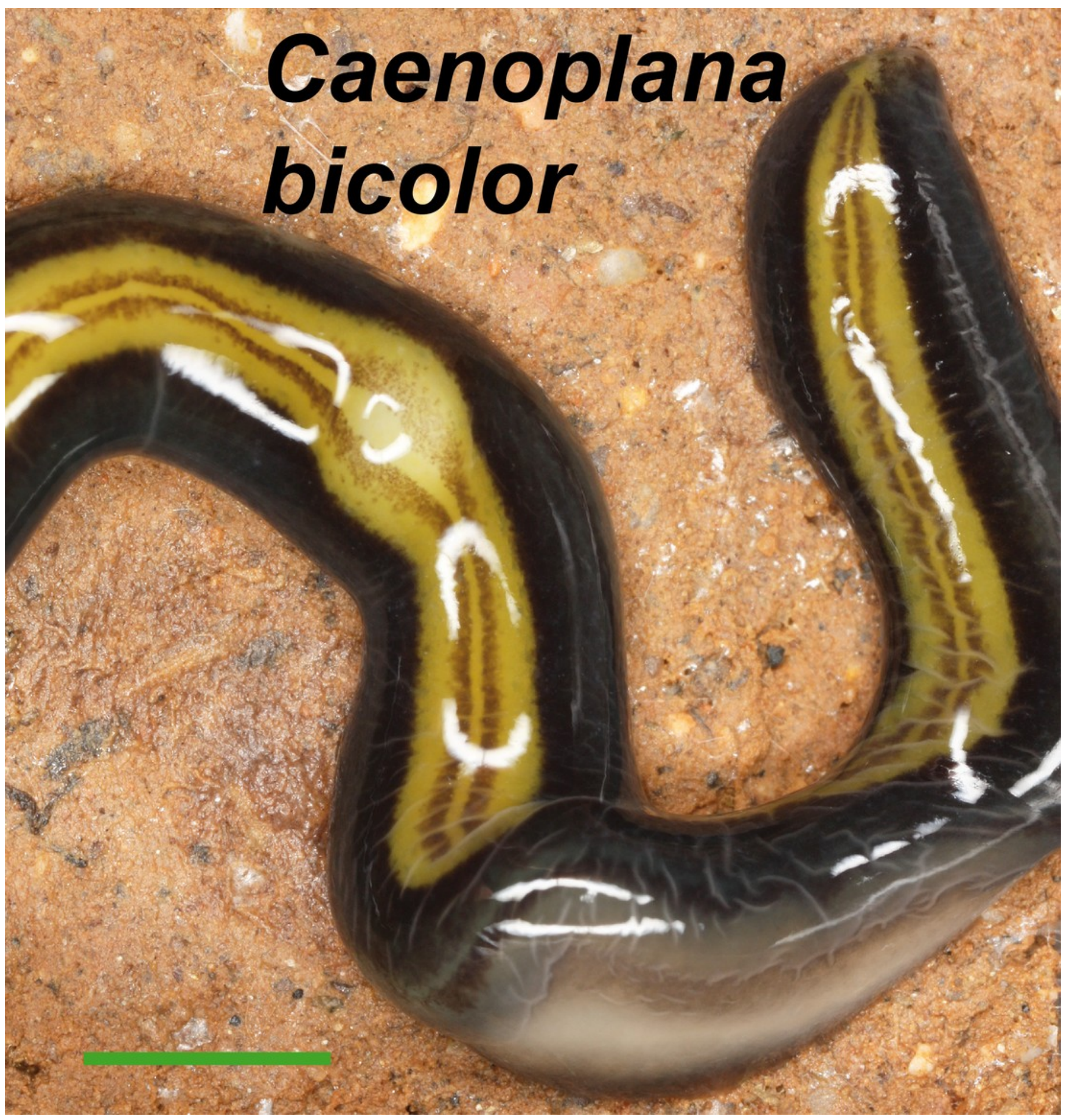




\section{Figure 6}

\section{Caenoplana morph Ca1.}

A, dorsal view. B, ventral view of median part. C, lateral view of anterior end showing line of eyes. Scale bar $5 \mathrm{~mm}$. 


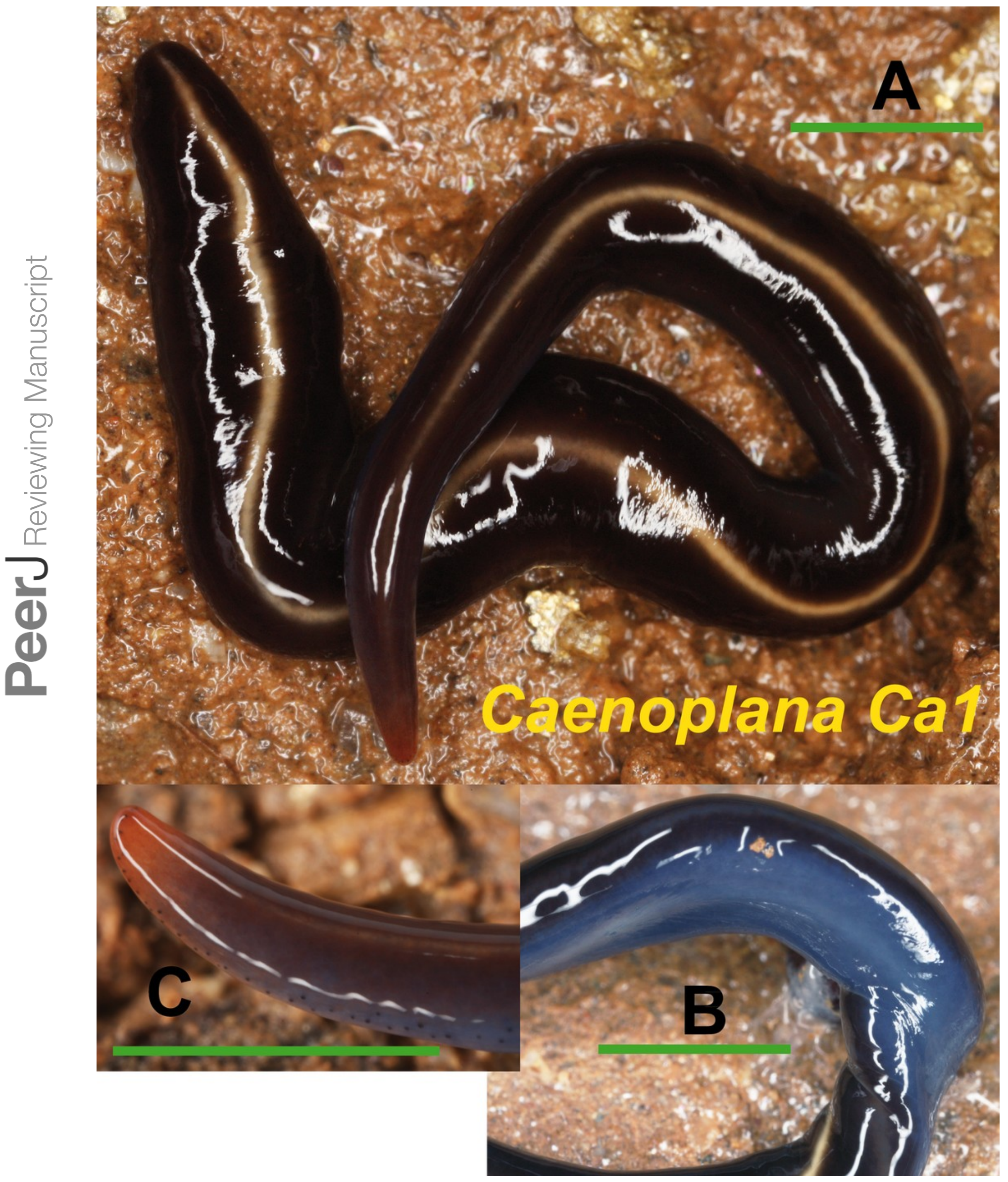




\section{Figure 7}

Caenoplana morph Ca2.

A, dorsal view. B, ventral view of median part and dorsal view of anterior end showing line of eyes. C, lateral view of anterior end showing line of eyes. Scale bar $5 \mathrm{~mm}$.

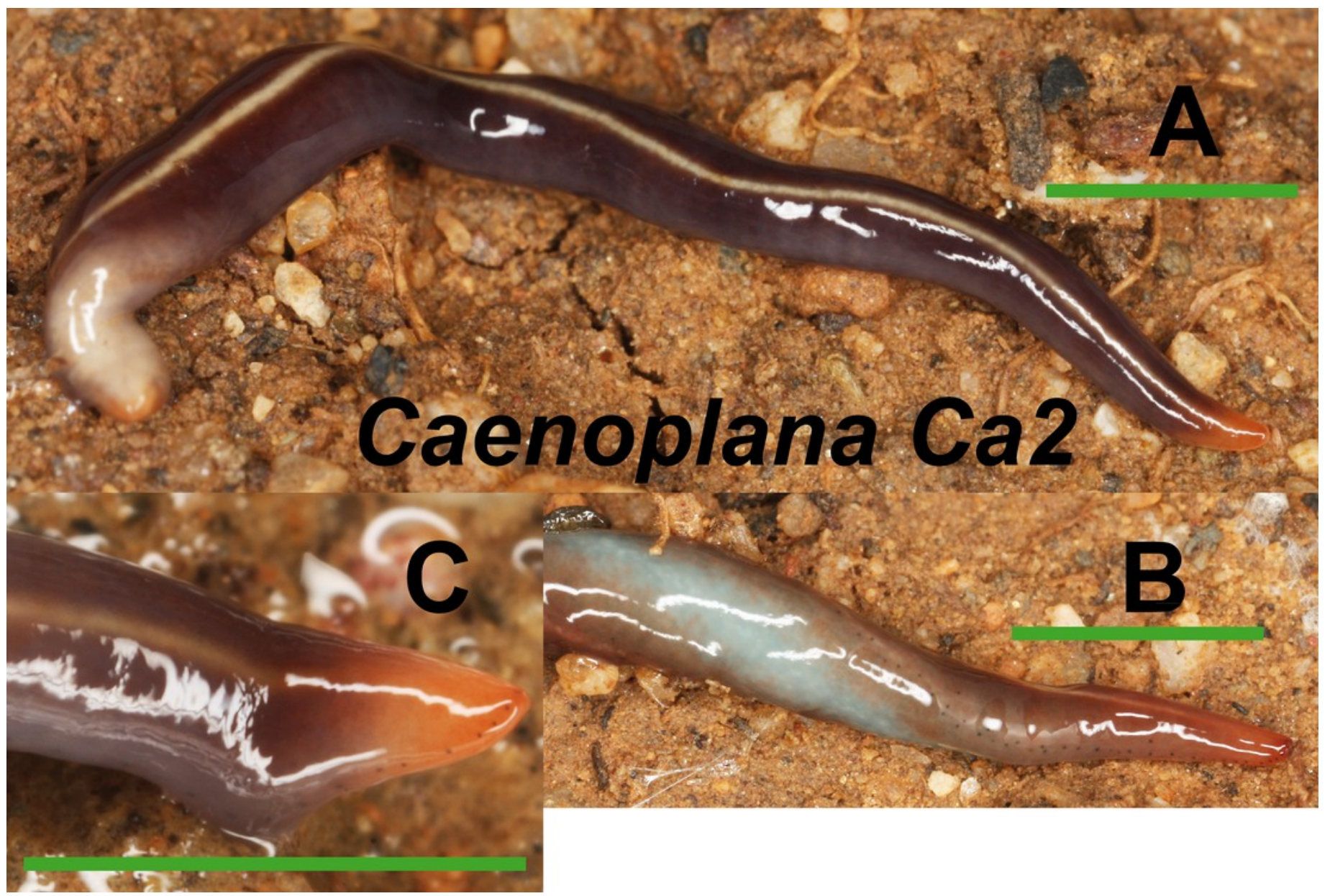




\section{Figure 8}

\section{Dolichoplana striata.}

$A$, dorsal view. $B$, ventral view of median part. C, lateral view of anterior end showing the eye spot. Scale bar $5 \mathrm{~mm}$. 


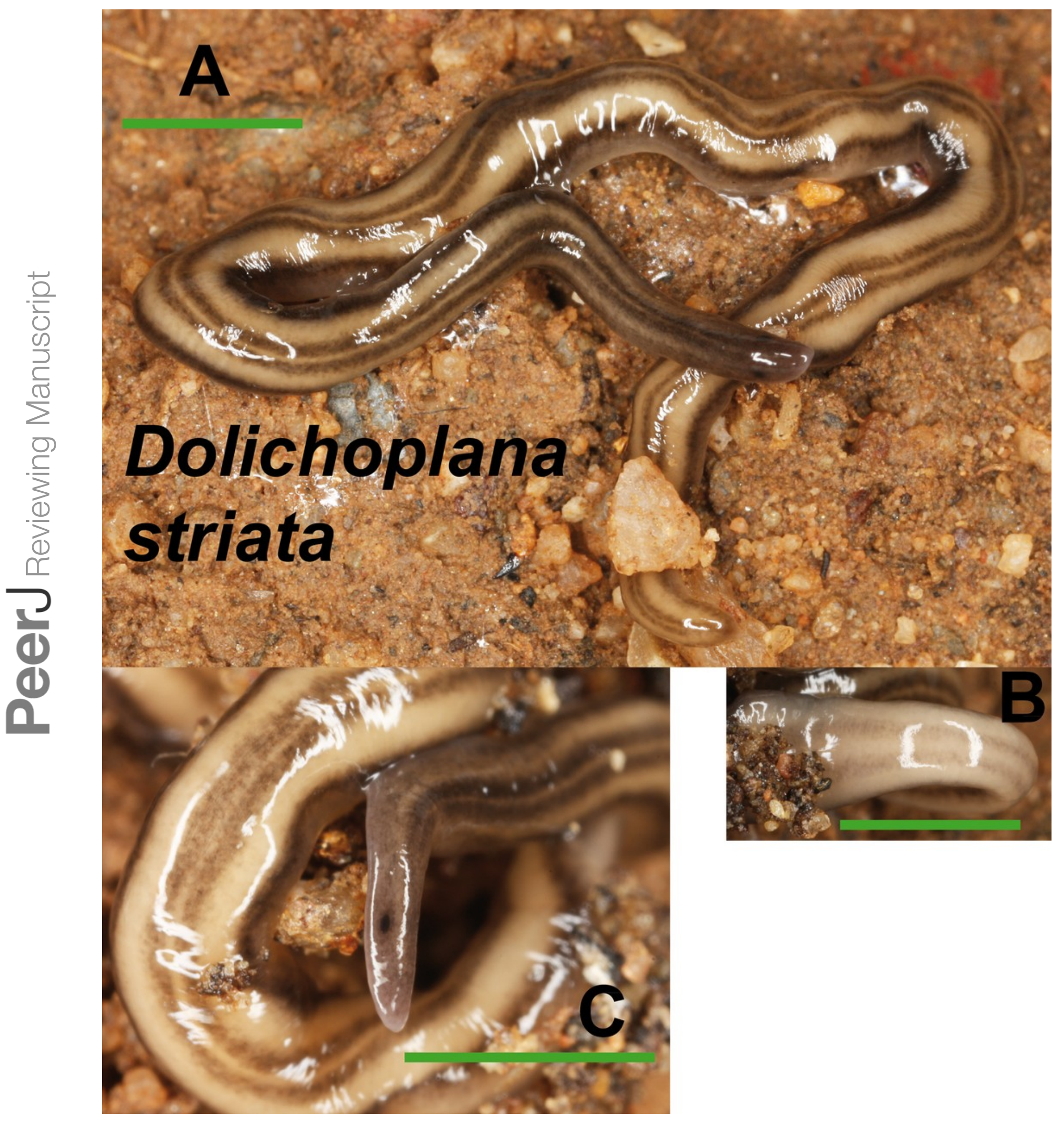




\section{Figure 9}

Kontikia ventrolineata.

A, dorsal view. B, ventral view of posterior end. C, lateral view of anterior end showing line of eyes. Scale bar $5 \mathrm{~mm}$.

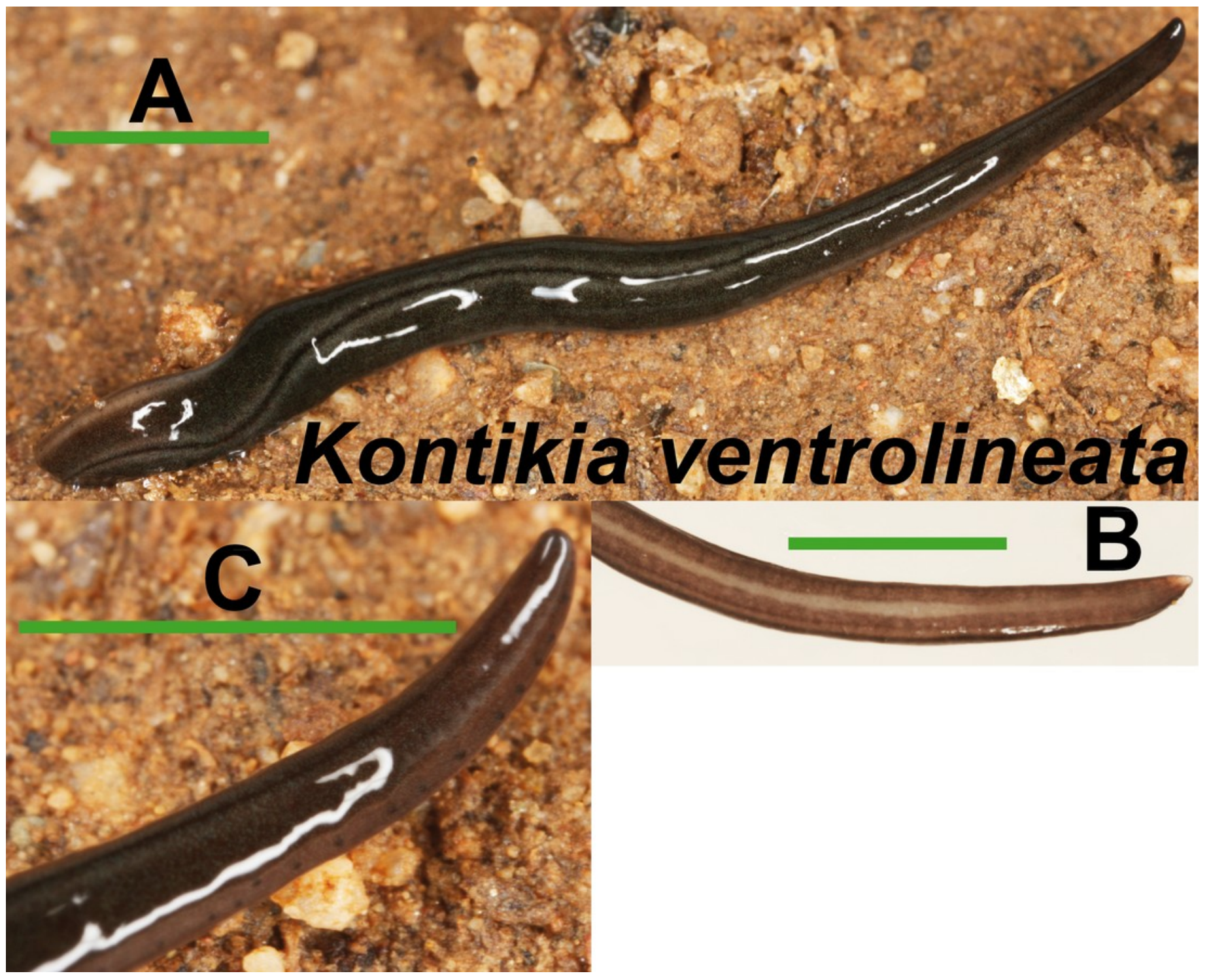




\section{Figure 10}

Rhynchodemus morph Rs1.

A, dorsal view, scale bar $5 \mathrm{~mm}$. B, lateral view of anterior region, scale bar $2.5 \mathrm{~mm}$.

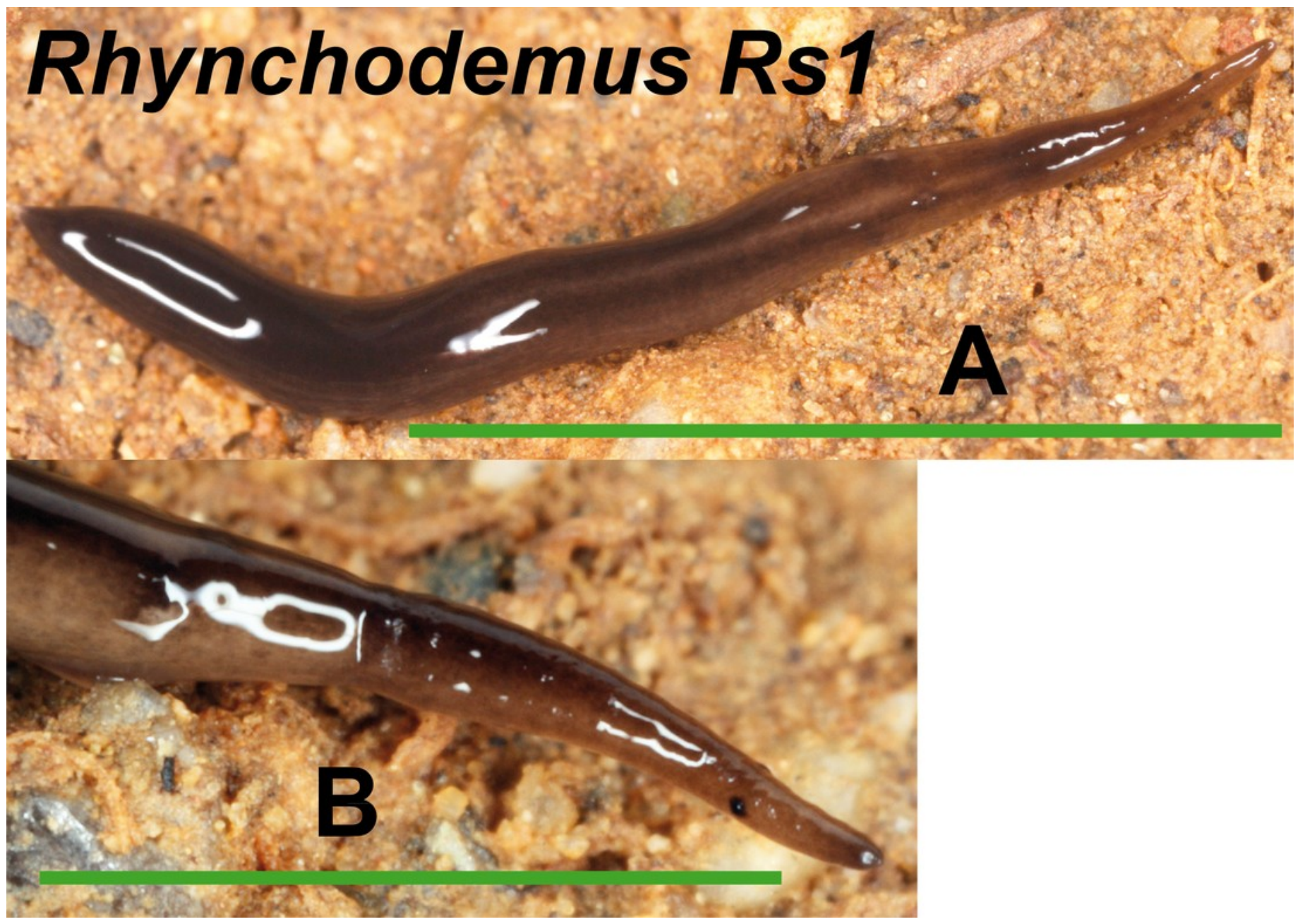




\section{Figure 11}

\section{Obama sp.}

A, dorsal view of two specimens (codes 434 and 610) from one Obama sp.A clade in the Geoplaninae Cox1 tree (Fig.14). B, dorsal view of two specimens (codes 437 and 594) from Obama sp.B clade in the Geoplaninae Cox1 tree (Fig.14). C, ventral view. D, lateral view of anterior end showing line of eyes. Scale bar $5 \mathrm{~mm}$.

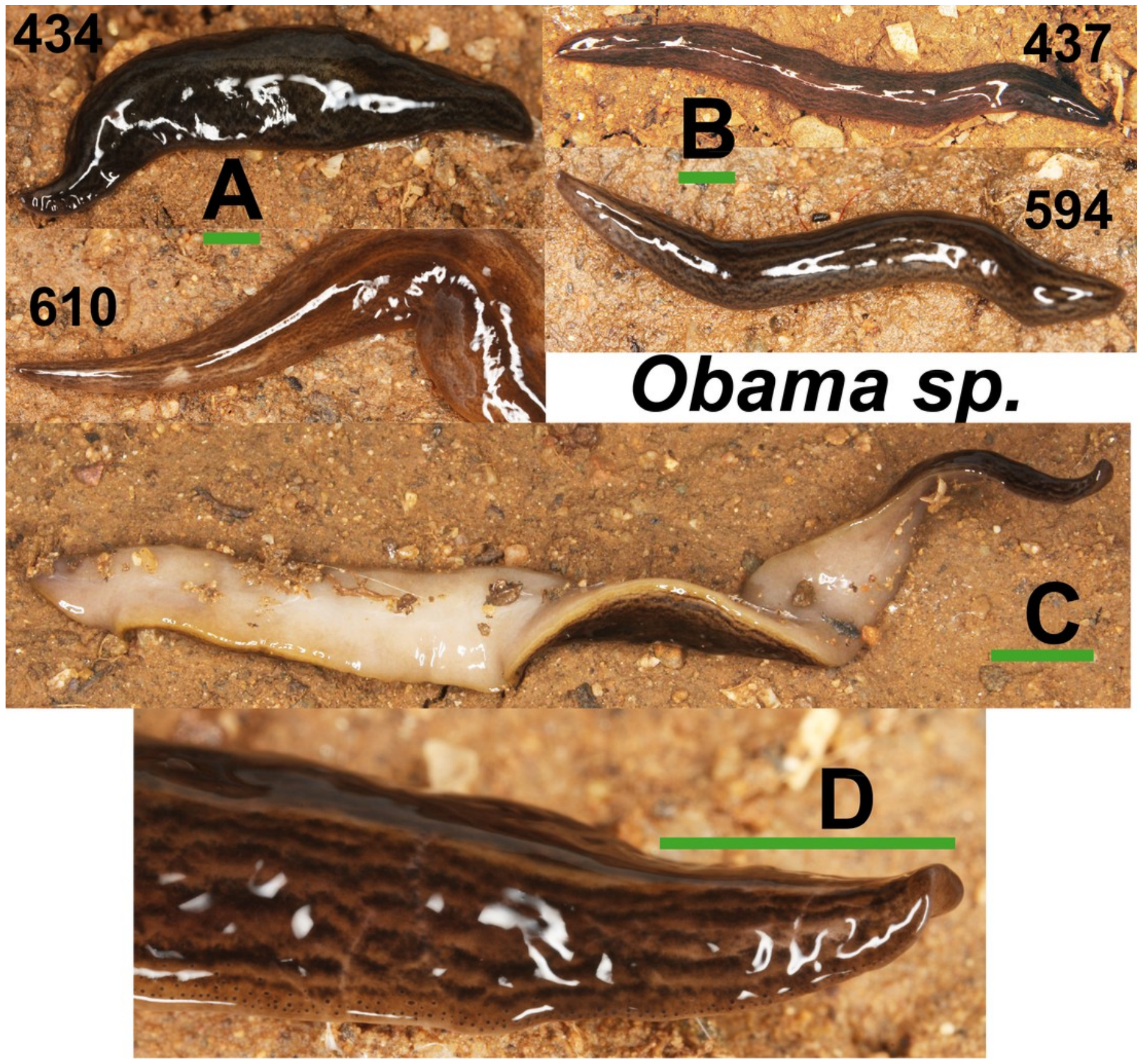




\section{Figure 12}

Maximum likelihood (ML) tree of the Geoplanidae subfamilies and tribes (Bipaliinae, Geoplaninae, Caenoplanini, and Rhynchodemini).

Tree inferred from the concatenated dataset (Cox1 and 28S genes). Three Dugesia species as outgroups. Values at nodes correspond to bootstrap (>75) for $\mathrm{ML}$ and posterior probability (PP) values from the Bayesian analysis $(>0.95)$.

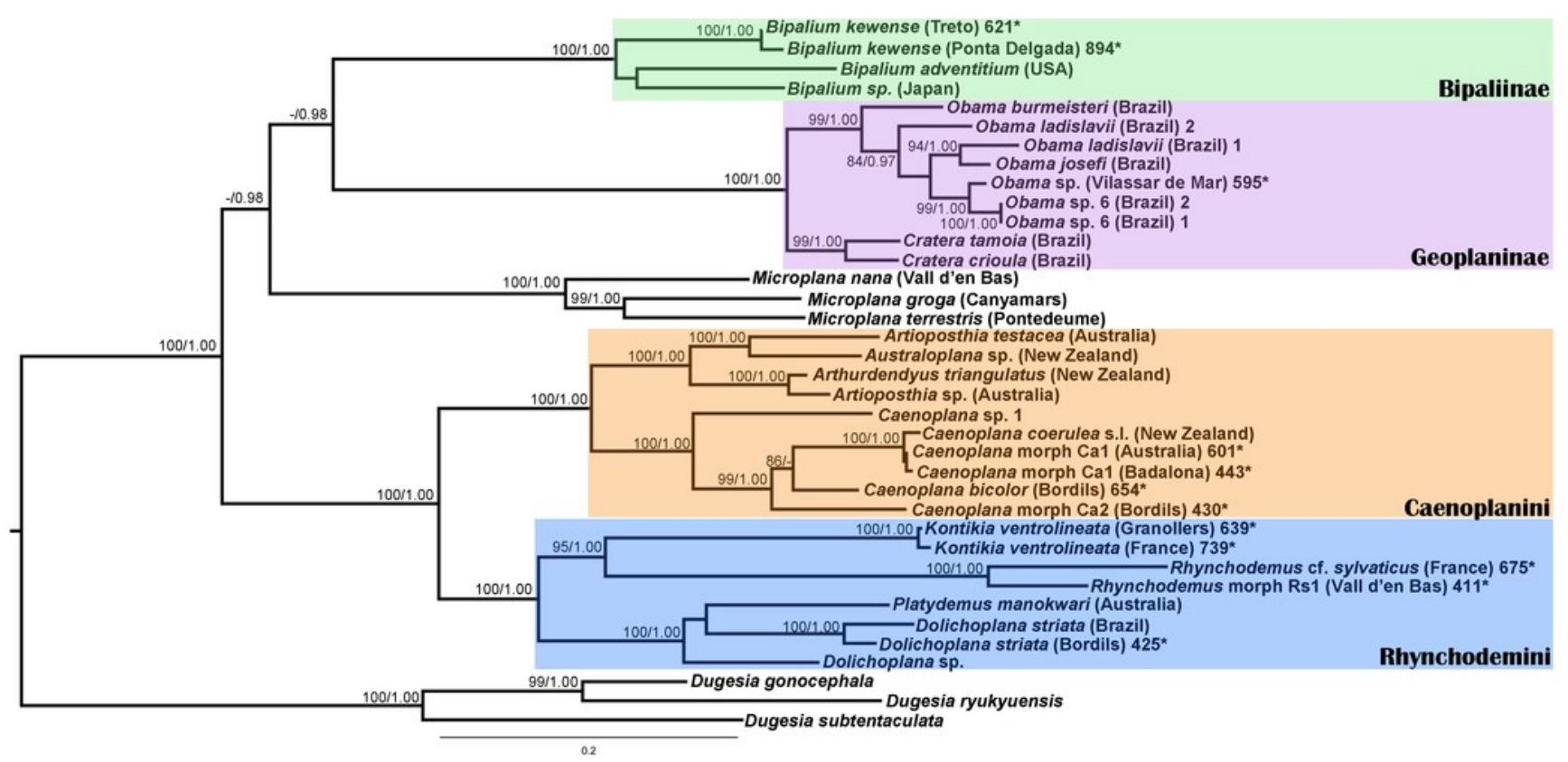




\section{Figure 13}

Bipaliinae dataset ML tree.

Tree inferred from the Cox1 gene. Three Microplana species as outgroups. Values at nodes correspond to bootstrap (>75) and PP (>0.95) values.

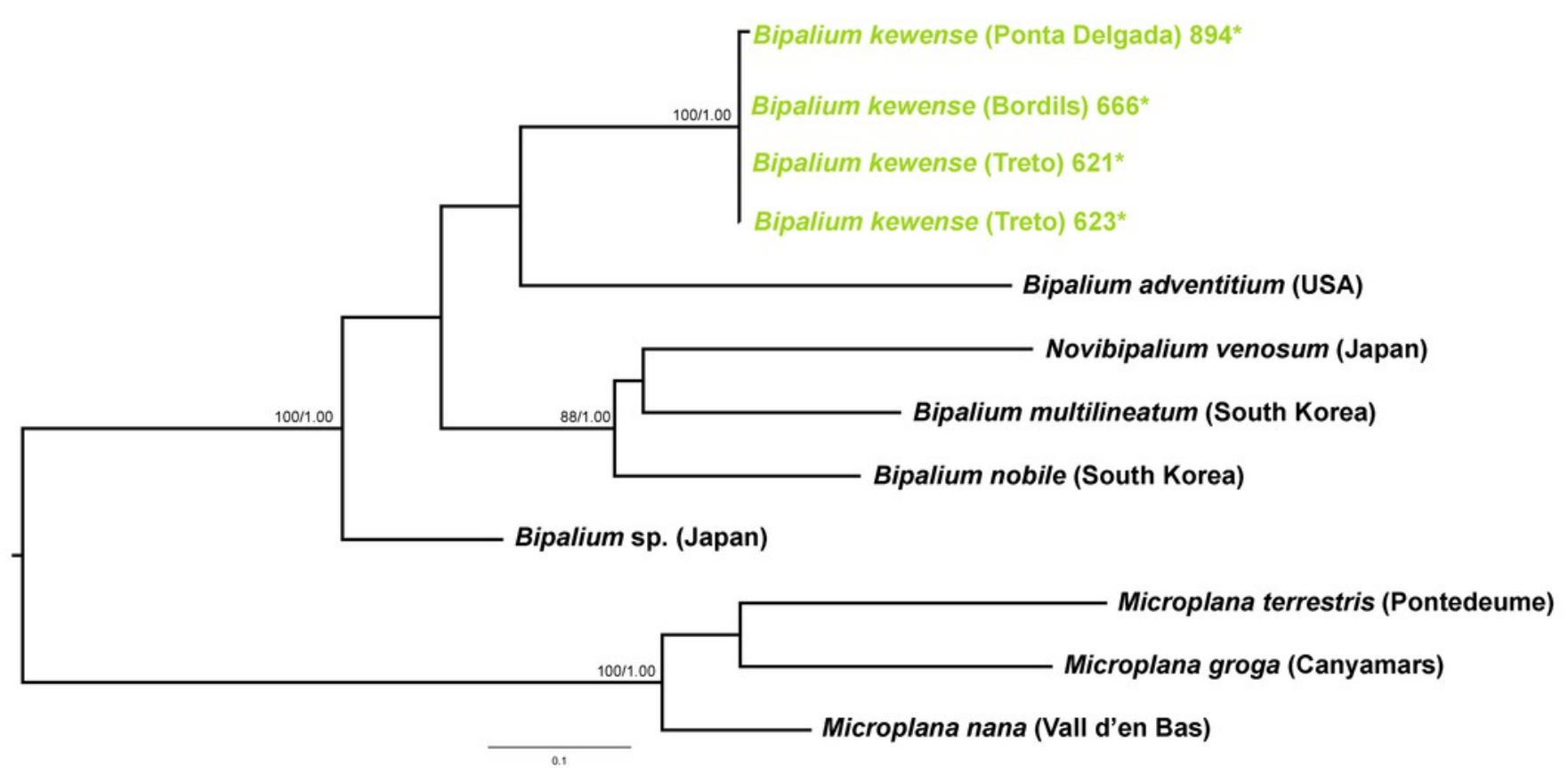




\section{Figure 14}

Geoplaninae dataset $\mathrm{ML}$ tree.

Tree inferred from the Cox1 gene. Two Cratera species as outgroups. Values at nodes correspond to bootstrap (>75) and PP (>0.95) values.

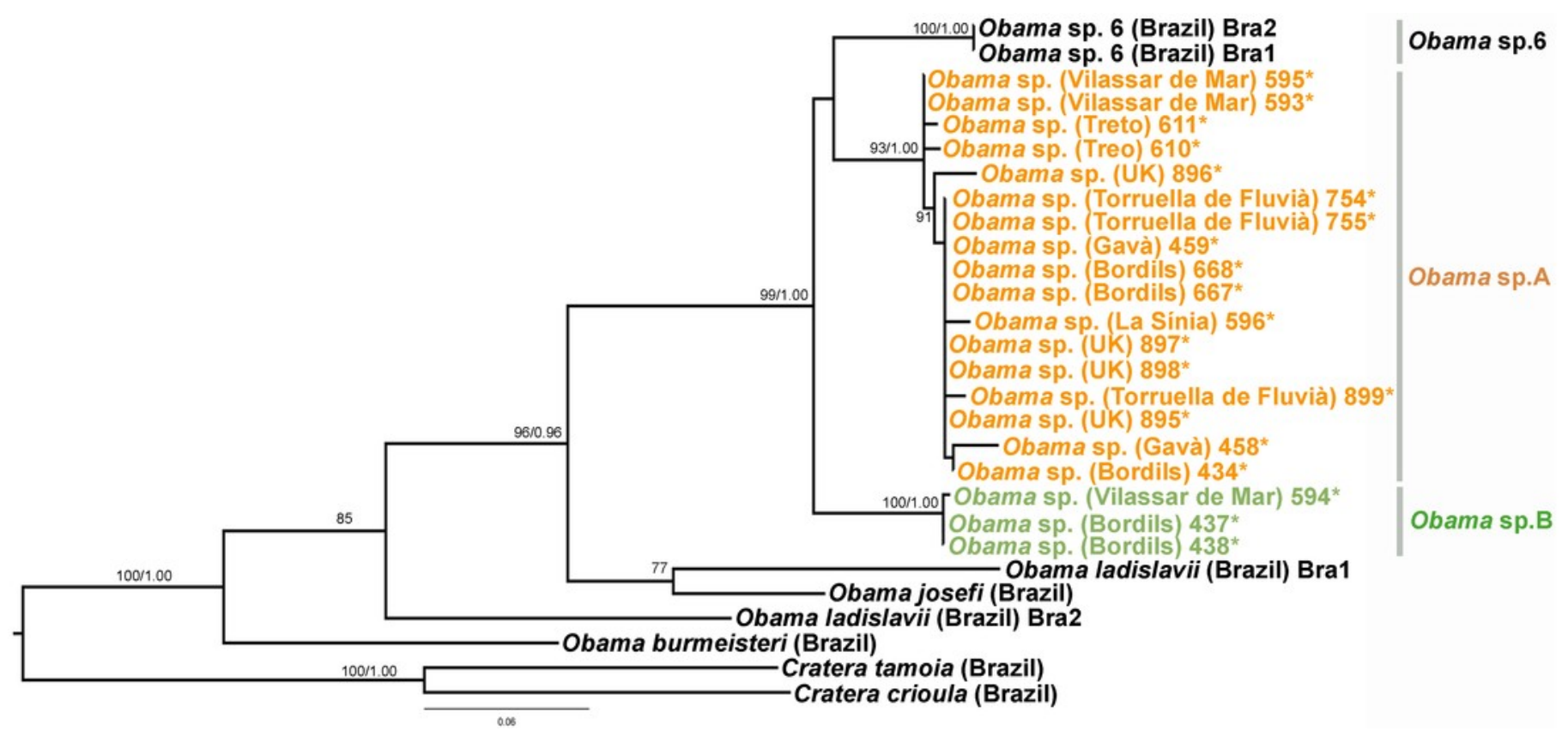




\section{Figure 15}

Caenoplanini dataset ML tree.

Tree inferred from the Cox1 gene. One Rhynchodemus species, one Platydemus species, and two Dolichoplana species as outgroups. Values at nodes correspond to bootstrap $(>75)$ and PP (>0.95) values.

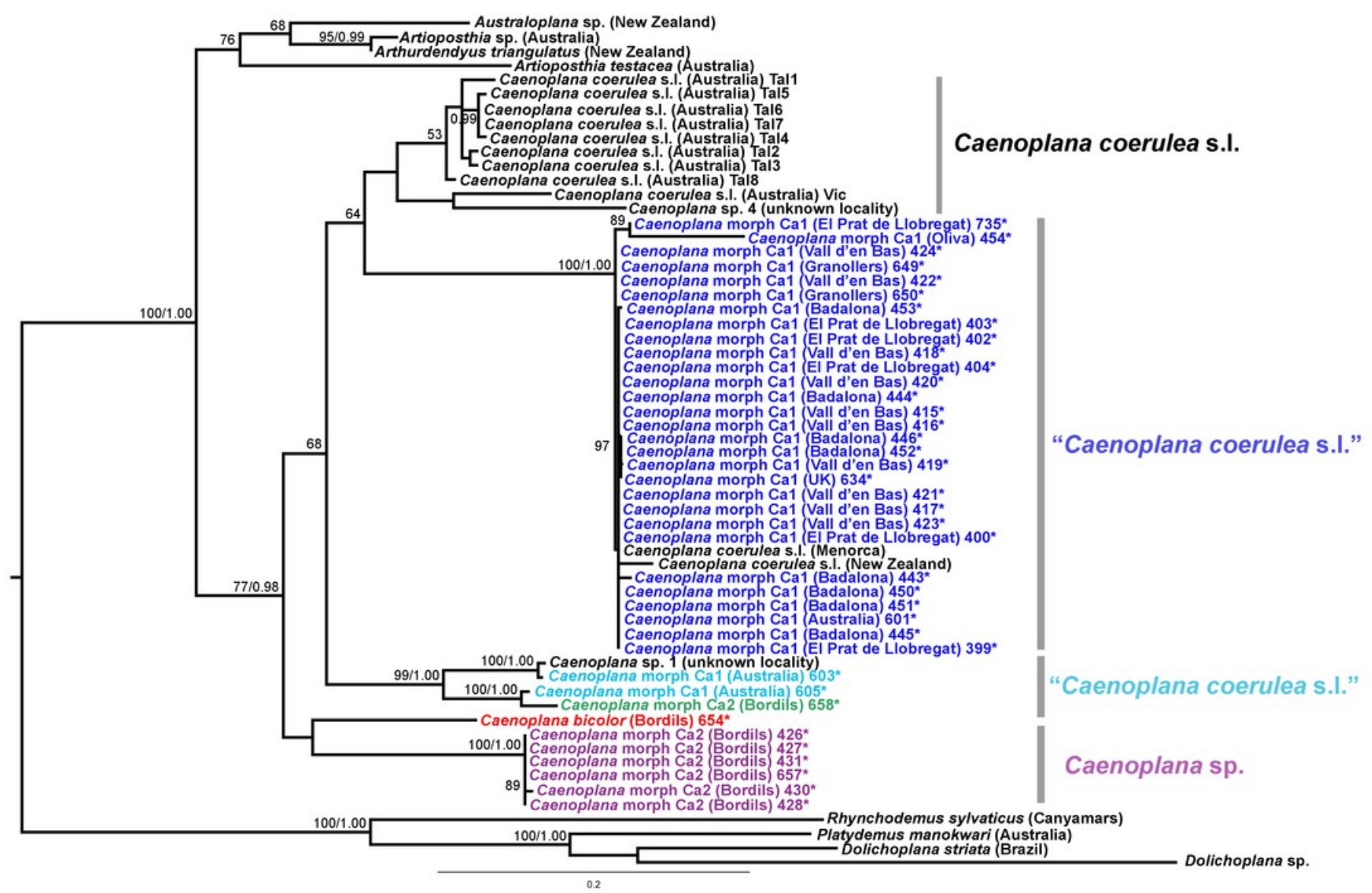




\section{Figure 16}

Rhynchodemini dataset ML tree.

Tree inferred from the Cox1 gene. One species of genres Arthurdendyus, Artioposthia, Australoplana and Caenopolana as outgroups. Values at nodes correspond to bootstrap $(>75)$ and PP (>0.95) values.

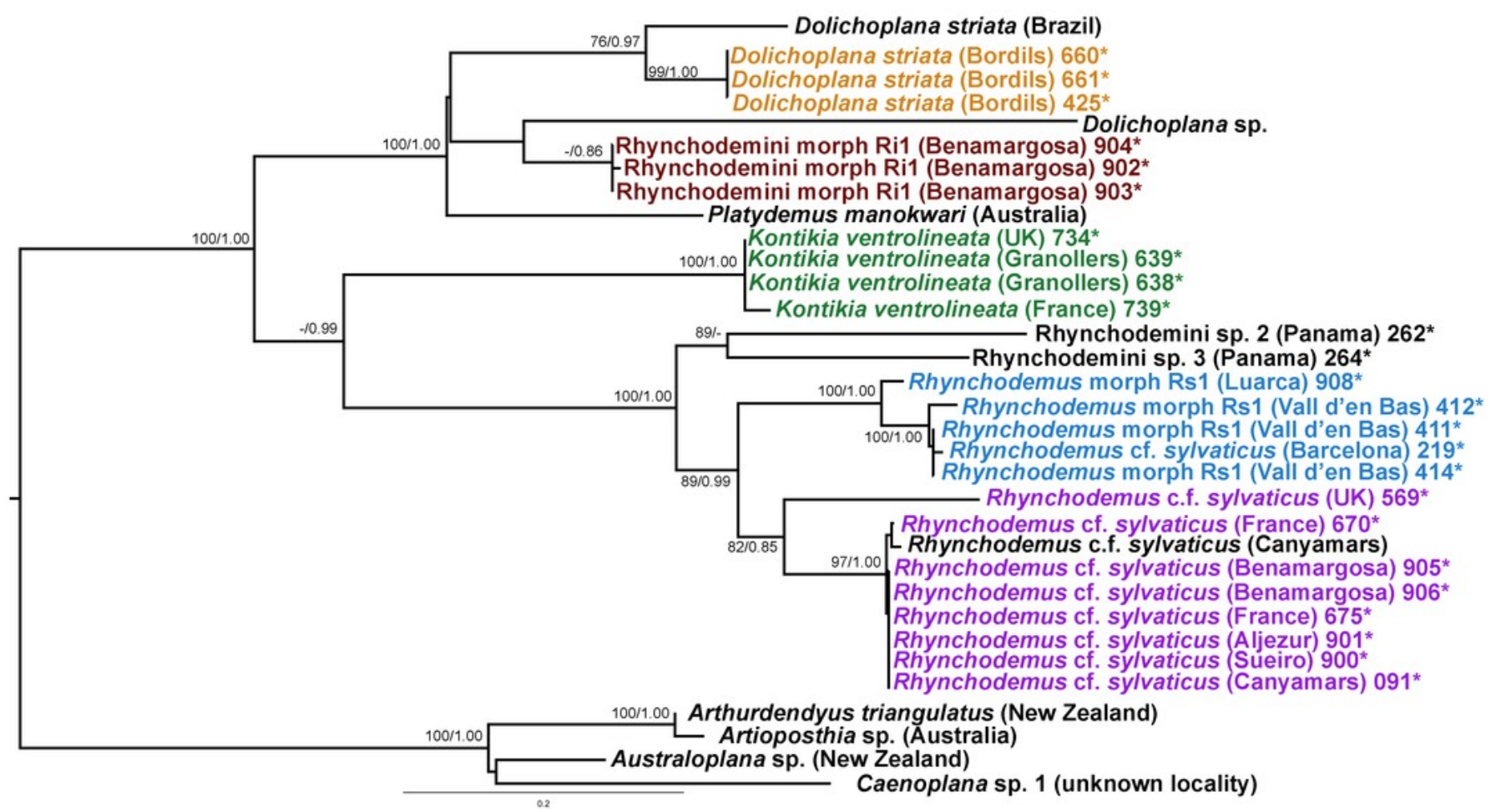




\section{Figure 17}

Potential distribution of Caenoplana coerulea species across the Iberian Peninsula.

The color gradient indicates the predicted likelihood that the environmental conditions suitable for the species based on the MaxEnt average output. Letters indicate localities where $C$. coerulea has been found, locality codes correspond to those in Table 1.

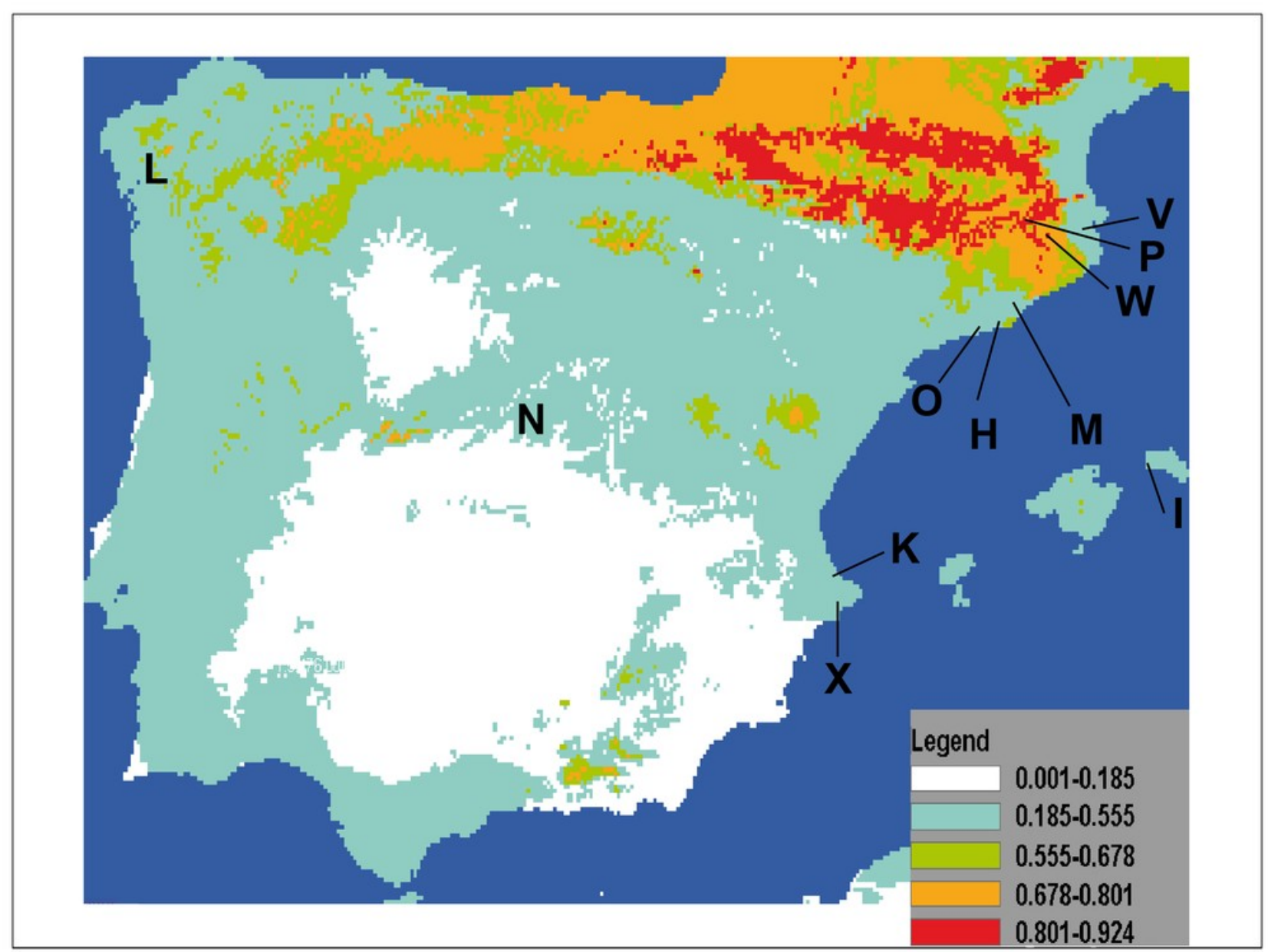

